\title{
A systematic review of methods to assess intake of sugar-sweetened beverages among healthy European adults and children: a DEDIPAC (DEterminants of Dlet and Physical Activity) study
}

\author{
Fiona Riordan ${ }^{1, *}$, Kathleen Ryan ${ }^{2}$, Ivan J Perry ${ }^{1}$, Matthias B Schulze ${ }^{3}$, \\ Lene Frost Andersen ${ }^{4}$, Anouk Geelen ${ }^{5}$, Pieter van't Veer ${ }^{5}$, Simone Eussen ${ }^{6}$, \\ Martien van Dongen ${ }^{6}$, Nicole Wijckmans-Duysens ${ }^{6}$ and Janas M Harrington ${ }^{1}$ \\ ${ }^{1}$ Department of Epidemiology and Public Health, University College Cork, Western Road, Cork, Republic of Ireland: \\ ${ }^{2}$ School of Applied Psychology, University College Cork, Cork, Republic of Ireland: ${ }^{3}$ Department of Molecular \\ Epidemiology, German Institute of Human Nutrition, Potsdam-Rehbrücke, Germany: ${ }^{4}$ Department of Nutrition, \\ Institute of Basic Medical Sciences, University of Oslo, Oslo, Norway: ${ }^{5}$ Division of Human Nutrition, Wageningen \\ University, Wageningen, The Netherlands: ${ }^{6}$ Department of Epidemiology of the Faculty of Health, Medicine and \\ Life Sciences, Maastricht University, Maastricht, The Netherlands
}

Submitted 24 September 2015: Final revision received 19 August 2016: Accepted 24 August 2016: First published online 21 October 2016

\begin{abstract}
Objective: Research indicates that intake of sugar-sweetened beverages (SSB) may be associated with negative health consequences. However, differences between assessment methods can affect the comparability of intake data across studies. The current review aimed to identify methods used to assess SSB intake among children and adults in pan-European studies and to inform the development of the DEDIPAC (DEterminants of DIet and Physical Activity) toolbox of methods suitable for use in future European studies.

Design: A literature search was conducted using three electronic databases and by hand-searching reference lists. English-language studies of any design which assessed SSB consumption were included in the review.

Setting: Studies involving two or more European countries were included in the review.

Subjects: Healthy, free-living children and adults.

Results: The review identified twenty-three pan-European studies which assessed intake of SSB. The FFQ was the most commonly used ( $n$ 24), followed by the $24 \mathrm{~h}$ recall $(n 6)$ and diet records $(n 1)$. There were several differences between the identified FFQ, including the definition of SSB used. In total, seven instruments that were tested for validity were selected as potentially suitable to assess SSB intake among adults ( $n$ 1), adolescents ( $n$ 3) and children ( $n$ 3).

Conclusions: The current review highlights the need for instruments to use an agreed definition of SSB. Methods that were tested for validity and used in panEuropean populations encompassing a range of countries were identified. These methods should be considered for use by future studies focused on evaluating consumption of SSB.
\end{abstract}

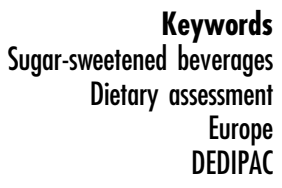

A poor-quality diet is associated with non-communicable diseases $^{(1-4)}$ and there is a growing body of research indicating that the consumption of sugar-sweetened beverages (SSB) may be associated with negative health consequences, including the development of metabolic syndrome and higher blood pressure ${ }^{(5)}$, an increased risk of diabetes ${ }^{(6)}$, increased body weight ${ }^{(7)}$ and obesity ${ }^{(8)}$. One of the recommendations made by the WHO Global
Strategy on Diet and Physical Activity is the limiting of sugar and salt intake ${ }^{(9)}$. SSB include drinks that are sweetened with sugar, other calorific sweeteners and corn syrups, as well as encompassing carbonated and noncarbonated drinks. In recent years there has been a global increase in the consumption of $\mathrm{SSB}^{(10,11)}$, which are characterised by their low nutritional content and failure to provide a feeling of fullness ${ }^{(12)}$. 
Recent studies suggest that levels of overweight and obesity are increasing in Europe ${ }^{(13,14)}$. However, while evidence suggests that reducing the intake of SSB would lead to a significant reduction in the incidence of obesity as well as other chronic illness such as diabetes (type $2)^{(15,16)}$, the link between obesity and intake of SSB is one that continues to be examined, with mixed results ${ }^{(8,17-22)}$. Many reasons for this inconsistency have been indicated, including methodological differences between studies and differing characteristics of assessment instruments, such as differences in the units of serving size, frequency categories and the definitions of SSB used ${ }^{(17)}$. Using standardised instruments and assessment methods across European populations has the potential to strengthen the investigation of associations between SSB and health outcomes such as obesity and to facilitate the collection of valid and comparable dietary intake data, along with the tracking of regional trends ${ }^{(23)}$.

There has been increasing focus on the standardisation and harmonisation of food classification systems and food composition databases between European countries (e.g. the International Food Data Systems Project, the Eurofoods initiative, the Food-Linked Agro-Industrial Research programme, COST Action 99, TRANSFAIR study, EUROFIR, etc.) ${ }^{(23-29)}$. The IDAMES (Innovative Dietary Assessment Methods in Epidemiological Studies and Public Health) project has evaluated new methods of dietary intake assessment in Europe ${ }^{(30)}$, developing the European Food Propensity Questionnaire for use in European countries. Although the European Food Safety Authority indicates that a computerised method (e.g. EPIC-SOFT or similar) should be used for collection of standardised dietary intake data at the European level ${ }^{(31,32)}$, standards have not yet been developed for the assessment of dietary intake, including intake of SSB, as part of aetiological studies. Thematic Area 1 of the DEDIPAC (Determinants of Diet and Physical Activity) project ${ }^{(33)}$, a pillar of the EU Joint Programme Initiative 'Healthy Diet for a Healthy Life', in part aims to address this gap by determining the most effective, harmonised methods of dietary intake assessment and preparing a toolkit of the most useful measurement tools of dietary intake that can be used extensively across Europe ${ }^{(33,34)}$. The aim of the current systematic literature review was to identify suitable assessment methods that may potentially be used to measure intake of SSB in European children and adults in pan-European studies. These methods will later be assessed for their effectiveness as part of their inclusion in the DEDIPAC toolkit.

\section{Methods}

\section{Data sources and study selection}

The current review adheres to the guidelines of the PRISMA (Preferred Reporting Items for Systematic Reviews and Meta-Analyses) Statement. The protocol for the review can be accessed from PROSPERO (CRD42014012890) ${ }^{(36)}$. A systematic literature search was conducted for panEuropean studies that assessed the intake of SSB. A definition of SSB that encompasses drinks with pre-added sugar, including soft drinks and energy drinks (carbonated and non-carbonated drinks) and cordials/squashes, was used; that is, the definition excluded drinks where sugar is added by the consumer (e.g. coffee and tea) and diet soft drinks. Two authors, F.R. and K.R., independently conducted a search of PubMed, EMBASE and Web of Science databases, using combinations of search terms for SSB such as 'carbonated drink/s', 'soft drink/s', 'fizzy drink/s', 'energy drink/s', 'sugar-sweetened beverage/s' and 'soda/s', along with keywords for dietary intake including 'diet', 'eating', 'consumption' and 'intake', and search terms for European countries (see online supplementary material, Supplemental Table 1). All searches were limited to literature published from 1990 through to 9 June 2014 (Fig. 1).

Titles and abstracts of the sourced articles were independently screened by F.R. and K.R. If in doubt regarding inclusion, the article was retained for full-text review. Any disagreement during the full-text review stage was resolved through consultation with a third author, J.M.H. Articles were included if they assessed the intake of SSB within two or more European countries (EU countries as defined by the Council of Europe) ${ }^{(36)}$. The aim of the review was to identify instruments that are suitable to assess SSB intake in the general, healthy adult or child populations. Therefore, study participants were required to be free-living, healthy populations of any age. Hospitalbased populations, along with studies which focused on a specific disease subgroup (e.g. diabetic patients) or any fixed societal subgroups (e.g. pregnant women), were excluded. If studies included or compared two cohorts, one of which was a healthy general population, they were included. Intervention studies were eligible provided intake of SSB was measured at baseline. Similarly, casecontrol studies were included if intake was assessed in population-based controls. Studies were included only if they assessed intake of SSB at the level of the individual; that is, studies which assessed household-level consumption of SSB were excluded (Fig. 1).

Reference lists of all included papers, along with relevant meta-analyses and literature reviews, were reviewed for further publications not identified by the original search. Databases were also searched using the names of individual European projects listed in the DEDIPAC Inventory of Relevant European Studies, a compilation of studies which is an ongoing part of DEDIPAC. Authors were contacted to obtain full versions of the relevant instruments or questionnaires and some articles, and the Endnote library of a concurrently occurring systematic literature review on methods to assess intake of fruits and vegetables $(\mathrm{F} \& \mathrm{~V})^{(37)}$ was reviewed for further studies. 


\section{Data extraction and quality assessment}

Data extraction was carried out using the same approach as outlined in the F\&V review ${ }^{(38)}$; that is, extracting details on study design, number and names of European countries involved, sample size (total and number for each country), age range of the included population, the method used and its description (including frequency categories for FFQ, total number of items/items that referred to SSB, details of nutrient intake assessment, details of portion estimation), mode of administration, and details on the validity or reproducibility testing. Originally sourced articles describing the methods in the most detail were selected for inclusion, with further information obtained from articles sourced from reference lists. One reviewer (F.R.) extracted the data for each study, which was confirmed by the other reviewer (K.R.).

As with the review of methods to assess F\&V intake ${ }^{(37)}$, a comprehensive quality appraisal of each included article was not conducted as part of the current review; however, relevant validation studies were referenced where possible and data were extracted from these studies by M.v.D., S.E. and N.W.-D. To determine which instruments would be appropriate to use in pan-European studies, two criteria were applied: (i) the instrument was tested for validity and/or reproducibility; and (ii) the instrument was used in more than two countries simultaneously that represent a range of European regions. A range implied that at least one country from at least three of the Southern, Northern, Eastern and Western European regions, as defined by the United Nations, were included ${ }^{(38)}$.

\section{Results}

\section{Description of the included studies}

The initial search identified 1949 papers, of which 1290 remained once duplicates were removed. After title and abstract screening, 1188 papers were excluded (Fig. 1).

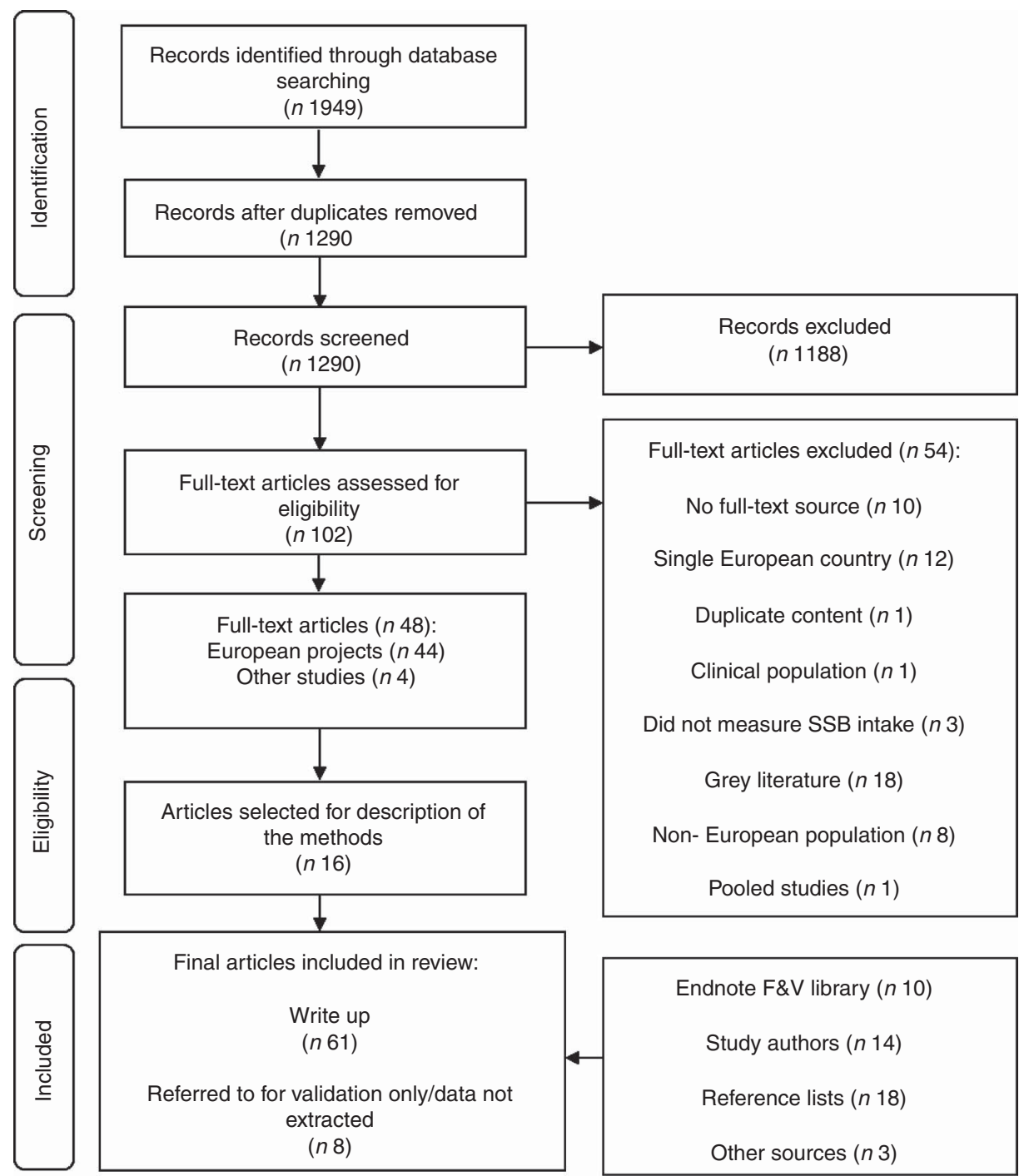

Fig. 1 Flow diagram showing study selection process for the current review (SSB, sugar-sweetened beverages; F\&V, fruits and vegetables) 
Full-text papers were sourced and reviewed for 102 papers, of which forty-eight were ultimately retained. These articles were grouped according to the major European project to which they belonged ( $n$ 44) or as 'Other' if they did not belong to a project ( $n$ 4; see Fig. 1 for breakdown of papers). From these forty-eight articles, sixteen articles were selected which best described the background to the project or the method used; one to three articles were typically selected per project, with the exception of the ToyBox study where articles obtained from authors were used in favour of the sourced article. Reviewing the reference lists yielded eighteen further articles in which the methods were described $^{(29,39-55)}$.

Fourteen further articles were obtained through correspondence with authors; and ten articles were obtained from the F\&V Endnote library, which identified seven additional studies assessing the intake of SSB, namely CNSHS (Cross National Student Health Survey) ${ }^{(56,57)}$, HAPIEE (Health, Alcohol and Psychosocial factors in Eastern Europe $)^{(58,59)}$, Finbalt Health Monitor ${ }^{(60)}$, MEDIS (MEDiterranean Islands Study) $^{(61)}$, MGSD (Mediterranean Group for the Study of Diabetes) ${ }^{(62)}$, ISAAC (International Study of Asthma and Allergies in Childhood) ${ }^{(63,64)}$ and the Finnish and Russian Karelia study ${ }^{(65)}$. Unpublished details on the instruments used as part of the I.Family Project ${ }^{(66)}$, successor to the IDEFICS (Identification and prevention of Dietary-and lifestyle-induced health EFfects In Children and infantS) study, were obtained through contact with the IDEFICS group. Articles on the background and validity testing as part of the Food4Me project, published after the search dates, were also added to the review ( $n 3)$. The characteristics of the included studies ${ }^{(29,39,40,42-58,62-119)}$ are described in Table 1.

As with the F\&V review ${ }^{(37)}$, the term 'study' refers to a larger project and not individual analyses/publications arising the same project and using the same methodology. In total, sixty-one articles on twenty-three studies were included in the current review: original search ( $n$ 16), from reference lists ( $n$ 18), from the concurrent F\&V review ( $n$ 10), from authors ( $n$ 14) and added subsequently ( $n$ 3). In total, twelve large pan-European studies were identified which assessed intake of $\operatorname{SSB}^{(29,39,44,50,51,62,64,66,67,80,105,110)}$ along with eleven smaller studies which typically were conducted in two to four countries ${ }^{(56,58,60,61,65,71-73,76,78,107)}$. Twelve studies assessed the intake of SSB in children, aged 3-6 years ${ }^{(82,83)}$, $2-9$ years $^{(39,40,79)}, 8-12$ years $^{(63,64)}$ or $10-12$ years $^{(51,76,77)}$, or adolescents $^{(39,44,66,67,71-73,76,78)}$. Fourteen studies assessed intake among adults only ${ }^{(29,42,56,59-62,65,72,103,107,110)}$, two of which assessed student populations ${ }^{56,107)}$. Three studies, the ENERGY (EuropeaN Energy balance Research to prevent excessive weight Gain among Youth), ToyBox and the I.Family projects, assessed both children and their parent or guardian $^{(51,66,80-90)}$. A further eight articles were sourced in which validity and/or reproducibility testing for the identified methods was described ${ }^{(91-94,96,99,120)}$.

\section{Dietary assessment methods}

\section{Types of methods}

Several methods were used to assess dietary intake of SSB in the identified studies, but most used FFQ (n 24) $)^{(47,51,54,56,59-65,67,69,71-73,76,82,101,103,107,110,121)}$. Other methods identified through the review were $24 \mathrm{~h}$ recalls $(24-\mathrm{HDR} ; \quad n \text { 6) })^{(48,51,52,78,113,122)}$ and diet records/diet diaries ${ }^{(102)}$. Most studies assessed intake of SSB using a single method, although four - ENERGY, IDEFICS and I.Family Project, and HELENA (Healthy Lifestyle in Europe by Nutrition in Adolescence) - used and described a second assessment methodology that supplemented or tested the study's primary method for validity. FFQ along with 24-HDR were used in the ENERGY, IDEFICS and HELENA projects. EPIC (European Prospective Investigation into Cancer and Nutrition) used a highly standardised 24-HDR, EPIC-SOFT, in a representative sub-sample from each cohort, which served as a common reference measurement across the different study populations, to calibrate and account for differences in the countryspecific FFQ used as part of the study ${ }^{(50,92,112)}$. Since a common FFQ instrument was not used across all countries in EPIC, only the EPIC-SOFT instrument is discussed in the present review. Similarly, as the EYHS (European Youth Heart Study) FFQ was reported as part of the Danish component of the study, so only the $24-\mathrm{HDR}$, preceded by the $1 \mathrm{~d}$ record, is discussed herein.

According to the two selection criteria (Table 1), several study instruments appeared appropriate to assess intake of SSB in future pan-European studies. Instruments that had been used among adult populations and that fulfilled the criteria included EPIC-SOFT, the Food4Me FFQ, the SENECA (Survey in Europe on Nutrition and the Elderly; a Concerted Action) modified dietary history method, the ToyBox Primary Caregiver's Questionnaire and the ENERGY parent questionnaire. Three instruments used to assess intake among adolescents, namely HELENA-DIAT (Dietary Assessment Tool), the HELENA online FFQ and the HBSC (Health Behaviour in Schoolaged Children) FFQ, fulfilled the criteria, as did the IDEFICS 24-HDR (SACINA) and Children's Eating Habits Questionnaire (CEHQ-FFQ), the ENERGY Children's Questionnaire (FFQ and pre-coded 24-HDR) and the ToyBox Children's Questionnaire (FFQ), all of which were used among children. The I.Family instrument was based on those developed for the IDEFICS study. The 24-HDR preceded by the $1 \mathrm{~d}$ qualitative food record used in the EYHS was tested for validity among children from the USA but not in a European population ${ }^{(99)}$. The 24-HDR was compared with observational data on consumption collected by parents and teachers. The instruments selected according to the two criteria are indicated by ticks in Table 1. However, in order to make the review more comprehensive, details on all the identified methods are provided. 


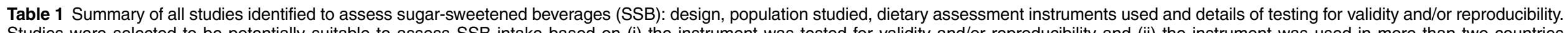

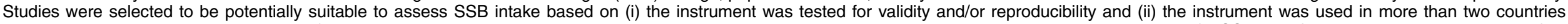

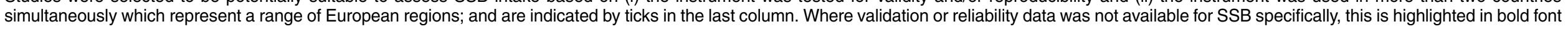

\begin{tabular}{|c|c|c|c|c|c|c|c|c|c|}
\hline Study & Design & Population & Countries & Instrument(s) & Tested for validity & $\begin{array}{c}>2 \text { countries/ } \\
\text { range }\end{array}$ & Validity & Reproducibility & $\begin{array}{c}\text { Instrument } \\
\text { selected }\end{array}$ \\
\hline $\begin{array}{l}\text { Adults } \\
\text { CNSHS } \\
(56,57)\end{array}$ & Cross-sectional & $\begin{array}{l}\text { Adults/students } \\
(n 2651)\end{array}$ & $\begin{array}{l}4 \text { (Germany, Denmark, Poland, } \\
\text { Bulgaria) }\end{array}$ & $\mathrm{FFQ}$ & & $\mathrm{x}$ & $\begin{array}{l}\text { No test of validity was performed, but the } \\
\text { questionnaire was similar to other FFQ that }\end{array}$ & No details & \\
\hline ENERGY $Y^{(51,77,108)}$ & Cross-sectional & $\begin{array}{l}\text { Age range NR } \\
\text { Adults/parents or } \\
\text { guardians } \\
(n 6002) \\
\text { Age range NR }\end{array}$ & $\begin{array}{l}7 \text { (Belgium, Greece, Hungary, } \\
\text { Netherlands, Norway, } \\
\text { Slovenia, Spain) }\end{array}$ & $\begin{array}{l}\text { Questionnaire with } \\
\text { FFQ and 24-HDR }\end{array}$ & $x^{(51)}$ & $\mathrm{x}$ & $\begin{array}{l}\text { had been tested for validity } \\
\text { No details } \dagger\end{array}$ & $\begin{array}{l}\text { The reliability and content validity of the } \\
\text { parent questionnaires were tested } \\
\text { separately in all participating countries, in } \\
\text { five schools per country, using } \\
\text { approximately } 50 \text { parents per country for } \\
\text { the reliability study and } 20 \text { parents for the } \\
\text { construct validity study } \\
\text { Unpublished data }\end{array}$ & $\checkmark$ \\
\hline $\operatorname{EPIC}^{(29,4749,109)}$ & Longitudinal & $\begin{array}{l}\text { Adults }(n 519978) \\
30-70 \text { years }\end{array}$ & $\begin{array}{l}10 \text { (Italy, Spain, Netherlands, } \\
\text { Germany, Sweden(Malmo)/ } \\
\text { Sweden (Umea), Denmark, } \\
\text { France, Greece, Norway, } \\
\text { England) }\end{array}$ & $\begin{array}{l}\text { FFQ, 24-HDR (EPIC- } \\
\text { SOFT) }\end{array}$ & $x^{(91)}$ & $\mathrm{x}$ & $\begin{array}{l}\text { Country-specific FFQ were tested for } \\
\text { validity } 921 \text {. Data obtained from highly } \\
\text { standardised 24-HDR, EPIC-SOFT, } \\
\text { carried out in a random sample of each } \\
\text { EPIC cohort, were used to account for } \\
\text { differences in the FFQ, reducing the } \\
\text { measurement error of the FFQ by } \\
\text { calibration } \\
\text { EP(109) } \\
\text { EPIC-SOFT was tested for validity against } \\
\text { biomarkers as part of the EFCOVAL } \\
\text { project(19) } \\
\text { No data on SSB }\end{array}$ & & $\checkmark$ \\
\hline ESCAREL $^{(110)}$ & Cross-sectional & $\begin{array}{l}\text { Adults }(n 3187) \\
18-35 \text { years }\end{array}$ & $\begin{array}{l}7 \text { (France, Spain, Italy, UK, } \\
\text { Finland, Latvia, Estonia) }\end{array}$ & FFQ & & & $\begin{array}{l}\text { No data on SSB } \\
\text { All questionnaires were tested for validity in } \\
\text { pilot studies }\end{array}$ & No details $\dagger$ & \\
\hline Finbalt Health Monitor ${ }^{(60)}$ & Cross-sectional & $\begin{array}{l}\text { Adults }(n 25044) \\
20-64 \text { years }\end{array}$ & $\begin{array}{l}4 \text { (Estonia, Finland, Latvia, } \\
\text { Lithuania) }\end{array}$ & FFQ $\neq$ & & & No details $\dagger$ & No details $\dagger$ & \\
\hline $\begin{array}{l}\text { Finnish and Russian } \\
\text { Karelia study (65) (as } \\
\text { reported as for the } 2002 \\
\text { study) }\end{array}$ & Cross-sectional & $\begin{array}{l}\text { Adults ( } n \text { 1201) } \\
25-64 \text { years }\end{array}$ & 2 (Russia, Finland) & FFQ & & & No details $\dagger$ & No details $\dagger$ & \\
\hline $\mathrm{Food}_{4 \mathrm{Me}}{ }^{(103-105)}$ & $\begin{array}{l}\text { Randomised } \\
\text { controlled trial }\end{array}$ & $\begin{array}{l}\text { Adults }(n 5562) \\
17-79 \text { years }\end{array}$ & $\begin{array}{l}7 \text { (Ireland, Netherlands; Spain, } \\
\text { Greece, UK, Poland, } \\
\text { Germany) }\end{array}$ & FFQ (web-based) & $X^{(104,105)}$ & $\mathrm{x}$ & $\begin{array}{l}\text { FFQ was tested for validity against } 4 \mathrm{~d} \text { non- } \\
\text { consecutive weighed records } \\
\text { crude correlations and exact level of } \\
\text { agreement } \\
\text { Good agreement with } 4 \mathrm{~d} \text { weighed food } \\
\text { record } \\
\text { Tested for validity against the EPIC-Norfolk } \\
\text { FFQ (105) using energy-adjusted } \\
\text { correlations, mean/median differences and } \\
\text { exact level of agreement } \\
\text { Good agreement with EPIC-Norfolk FFQ, } \\
\text { which has been tested for validity } \\
\text { Note: validation data available only for } \\
\text { 'other beverages' } \$\end{array}$ & $\begin{array}{l}\text { Reproducibility of the FFQ has been } \\
\text { tested }(104)\end{array}$ & $\mathrm{d}$ \\
\hline HAPIEE $^{(58) \star *}$ & Cross-sectional & $\begin{array}{l}\text { Adults }(n 28947) \\
45-69 \text { years }\end{array}$ & $\begin{array}{l}3 \text { (Russia, Poland, Czech } \\
\text { Republic) }\end{array}$ & FFQ $\neq$ & $X^{(93,94)}$ & & $\begin{array}{l}\text { The FFQ was based on the Whitehall II } \\
\text { questionnaire tested for validity by Brunner } \\
\text { et al.(.3) and Willett et al.(94) } \\
\text { No data on SSB }\end{array}$ & No details $\uparrow$ & \\
\hline I.Family Project ${ }^{(6,69,70)}$ & $\begin{array}{l}\text { Prospective } \\
\text { cohort study } \\
\text { (successor of } \\
\text { IDEFICS } \\
\text { study) }\end{array}$ & $\begin{array}{l}\text { Adults/parents } \\
(n>7000) \\
\text { Age range not } \\
\text { determined }\end{array}$ & $\begin{array}{l}8 \text { (Belgium, Cyprus, Estonia, } \\
\text { Germany Hungary, Italy, } \\
\text { Spain, Sweden) }\end{array}$ & $\begin{array}{l}\text { A diet questionnaire } \\
\text { (FFQ) was included } \\
\text { as part of the } \\
\text { parent } \\
\text { questionnaire } \\
\text { Online 24-HDR } \\
\text { (SACANA) }\end{array}$ & $\mathrm{x}$ & $\mathrm{x}$ & $\begin{array}{l}\text { Instruments are similar to those used in the } \\
\text { IDEFIIS project and these were tested for } \\
\text { validity }\end{array}$ & No details & \\
\hline Kolarzyk et al. ${ }^{(107)}$ & Cross-sectional & $\begin{array}{l}\text { Adults/students } \\
(n 1517) \text { (15) } \\
\text { Age range NR }\end{array}$ & $\begin{array}{l}4 \text { (Poland, Belarus, Russia, } \\
\text { Lithuania) }\end{array}$ & FFQ & & & $\begin{array}{l}\text { The FFQ has been tested for validity and } \\
\text { recommended by the National Food and } \\
\text { Nutrition Institute in Warsaw, Poland }\end{array}$ & No details $\dagger$ & \\
\hline MEDIS ${ }^{(61)}$ & Cross-sectional & Adults $(n 1190)$ & 2 (Cyprus, Greece) & $\mathrm{FFQ}$ & $X^{(89)}$ & & Tested for validitity ${ }^{(95)}$ & Tested for reproducibility ${ }^{(95)}$ & \\
\hline MGSD (62) & Cross-sectional & $\begin{array}{l}\text { Adults }(n \text { 425.54) } \\
\text { Non-diabetics } \\
(n 1833) \\
35-60 \text { years }\end{array}$ & $\begin{array}{l}6 \text { (Greece, Italy, Algeria, } \\
\text { Bulgaria, Egypt, Yugoslavia } \\
\text { (only diabetics in } \\
\text { Yugoslavia)) }\end{array}$ & $\begin{array}{l}\text { Dietary history method } \\
\text { using questionnaire }\end{array}$ & $x^{(40)}$ & & $\begin{array}{l}100 \text { subjects from various participating } \\
\text { centres were evaluated using the } 3 \mathrm{~d} \text { diet } \\
\text { diary (two weekdays and a Sunday) in } \\
\text { order to test the questionnaire for validity } \\
\text { No data on SSB }\end{array}$ & No details $\uparrow$ & \\
\hline
\end{tabular}


Table 1 Continued

\begin{tabular}{|c|c|c|c|c|c|c|c|c|c|}
\hline Study & Design & Population & Countries & Instrument(s) & Tested for validity & $\begin{array}{l}>2 \text { countries/ } \\
\text { range }\end{array}$ & Validity & Reproducibility & $\begin{array}{l}\text { Instrument } \\
\text { selected }\end{array}$ \\
\hline $\operatorname{SENECA}^{(42,43,50,102)}$ & $\begin{array}{l}\text { Mixed design } \\
\quad \text { (longitudinal } \\
\text { and cross- } \\
\text { sectional) }\end{array}$ & $\begin{array}{l}\text { Adults/elderly } \\
(n \sim 2600) \\
70-75 \text { years }\end{array}$ & $\begin{array}{l}12 \text { (Belgium, Denmark, France, } \\
\text { Greece, Hungary, Italy, } \\
\text { Netherlands, Norway, } \\
\text { Poland, Portugal, Spain, } \\
\text { Switzerland) }\end{array}$ & $\begin{array}{l}\text { Modified dietary } \\
\text { history method } \\
\text { comprising a } 3 \mathrm{~d} \\
\text { estimated record } \\
\text { and meal-based }\end{array}$ & $X^{(54,96)}$ & $x$ & $\begin{array}{l}\text { The cross-check dietary history method has } \\
\text { been tested for validity } 96) \\
\text { No data on SSB }\end{array}$ & No details $\dagger$ & $\checkmark$ \\
\hline ToyBox $^{(80-90)}$ & $\begin{array}{l}\text { Intervention } \\
\text { multifactorial } \\
\text { study }\end{array}$ & $\begin{array}{l}\text { Adults/parents or } \\
\text { guardians } \\
\text { ( } n 7056) \\
\text { (providing data } \\
\text { at baseline) }\end{array}$ & $\begin{array}{l}6 \text { (Belgium, Bulgaria, Germany, } \\
\text { Greece, Poland, Spain) }\end{array}$ & $\begin{array}{l}\text { Primary caregiver's } \\
\text { FFQ (PCQ) }\end{array}$ & $x^{(83)}$ & $x$ & No details $†$ & $\begin{array}{l}\text { Interval: } 2 \text { weeks } \\
\text { Reliability of the } P C Q \text { was tested( }{ }^{(83)} \\
\text { Note: validitity data available only for 'water' } \\
\text { and 'beverages' }\end{array}$ & \\
\hline HELENA $^{(44,45,52-55,68)}$ & Cross-sectional & $\begin{array}{c}\text { Adolescents } \\
(n 3000) \\
13-17 \text { years }\end{array}$ & $\begin{array}{l}9 \text { (Greece, Germany, Belgium, } \\
\text { France, Hungary, Italy, } \\
\text { Sweden, Austria, Spain) } \\
8 \text { countries used the 24-HDR } \\
\text { (as above, except Hungary) } \\
\text { Only } 5 \text { (Austria, Belgium, } \\
\text { Greece, Sweden, Germany) } \\
\text { pilot-tested the online FFQ }\end{array}$ & $\begin{array}{l}\text { 24-HDR using the } \\
\text { HELENA-DIAT } \\
\text { (Dietary } \\
\text { Assessment Tool)‡ } \\
\text { Online FFQ }\end{array}$ & $\begin{array}{l}X^{(52-54)} \\
X^{(54)}\end{array}$ & $\begin{array}{l}x \\
x\end{array}$ & $\begin{array}{l}\text { 24-HDR tested for validity against } 1 \mathrm{~d} \text { food } \\
\text { records and } 24-\mathrm{HDR}^{(52)} \text { using crude } \\
\text { correlations, mean/median differences and } \\
\text { exact level of agreement } \\
\text { Moderate to good agreement for 'soft drinks' } \\
\text { Self-report } 24-H D R \text { was compared with } \\
\text { interview-administered } 24-H D R \text { using } \\
\text { crude correlations and mean/median } \\
\text { differences, with good agreement } \\
\text { Online FFQ tested for validity against four } 24- \\
\text { HDR using crude correlations, mean/ } \\
\text { median differences( } \\
\text { (54) } \\
\text { Good agreement for 'soft drinks' }\end{array}$ & $\begin{array}{l}\text { Interval: } 1-2 \text { weeks } \\
\text { HELENA FFQ has adequate reliability }{ }^{(54)}\end{array}$ & $\checkmark$ \\
\hline I.Family Project ${ }^{(66,69,70)} \dagger$ & $\begin{array}{l}\text { Prospective } \\
\text { cohort study } \\
\text { (successor of } \\
\text { the IDEFICS } \\
\text { study) }\end{array}$ & $\begin{array}{l}\text { Adolescents } \\
(n>9000 \\
\text { children of } \\
\text { IDEFICs study } \\
\text { and their } \\
\text { siblings) } \\
12-17 \text { years }\end{array}$ & $\begin{array}{l}8 \text { (Belgium, Cyprus, Estonia, } \\
\text { Germany Hungary, Italy, } \\
\text { Spain, Sweden) }\end{array}$ & $\begin{array}{l}\text { A diet questionnaire } \\
\text { (FFQ) was included } \\
\text { as part of the teen } \\
\text { questionnaire } \\
\text { Online 24-HDR } \\
\text { (SACANA) }\end{array}$ & & & $\begin{array}{l}\text { The instruments are similar to those used and } \\
\text { tested for validity as part of the IDEFICS } \\
\text { project }\end{array}$ & No details $\dagger$ & \\
\hline Larsson et al. ${ }^{(71)}$ & Cross-sectional & $\begin{array}{l}\text { Adolescents } \\
(n \text { 2014) } \\
\text { Age range NR }\end{array}$ & 2 (Sweden, Norway) & FFQ $\ddagger$ & & & No details $†$ & No details $†$ & \\
\hline Szczepanska et al. ${ }^{(72)}$ & Cross-sectional & $\begin{array}{l}\text { Adolescents } \\
(n 404) \\
\text { Age range NR }\end{array}$ & 2 (Poland, Czech Republic) & $\mathrm{FFQ}$ & & & No details $\dagger$ & No detailst & \\
\hline TEMPEST T $^{(73-75)}$ & Cross-sectional & $\begin{array}{l}\text { Adolescents } \\
(n 2764) \\
12-17 \text { years }\end{array}$ & $\begin{array}{l}4 \text { (Netherlands, Poland, UK, } \\
\text { Portugal) }\end{array}$ & FFQ $\ddagger$ & & $\mathrm{x}$ & No details $\dagger$ & No details $\dagger$ & \\
\hline $\begin{array}{l}\text { Children } \\
\text { Cinar and Murtomaa }\end{array}$ & Cross-sectional & $\begin{array}{l}\text { Children }(n 619) \\
10-12 \text { years }\end{array}$ & 2 (Turkey, Finland) & Youth FFQ‡ & & & No details $\dagger$ & No details $\dagger$ & \\
\hline ENERGY $Y^{(51,77)}$ & Cross-sectional & $\begin{array}{l}\text { Children }(n 7234) \\
10-12 \text { years }\end{array}$ & $\begin{array}{l}7 \text { (Belgium, Greece, Hungary, } \\
\text { Netherlands, Norway, } \\
\text { Slovenia, Spain) }\end{array}$ & $\begin{array}{l}\text { Questionnaire with } \\
\text { FFQ and 24-HDR } \neq\end{array}$ & $X^{(98)}$ & $\mathrm{x}$ & $\begin{array}{l}\text { Construct validity assessed by comparing } \\
\text { self-complete questionnaire against } \\
\text { questionnaire completed by interview } \\
\text { using exact level of agreement(98) } \\
\text { Moderate to good construct validity for 'soft } \\
\text { drinks' }\end{array}$ & $\begin{array}{l}\text { Interval: } 1 \text { week } \\
\text { Moderate to good reliability }\end{array}$ & $\checkmark$ \\
\hline
\end{tabular}




\begin{tabular}{|c|c|c|c|c|c|c|c|c|c|}
\hline Study & Design & Population & Countries & Instrument(s) & Tested for validity & $\begin{array}{l}>2 \text { countries } / \\
\text { range }\end{array}$ & Validity & Reproducibility & $\begin{array}{l}\text { Instrument } \\
\text { selected }\end{array}$ \\
\hline $\mathrm{EYHS}^{(46,48,78)}$ & Cross-sectional & $\begin{array}{l}\text { Children ( } n 4000) \\
9 \text { and } 15 \text { years }\end{array}$ & $\begin{array}{l}4 \text { (Denmark, Portugal, Estonia, } \\
\text { Norway) } \\
\text { (sourced studies involve only } \\
\text { Denmark) }\end{array}$ & $\begin{array}{l}\text { FFQ, } 24-H D R, 1 d \\
\text { qualitative food } \\
\text { record }\end{array}$ & $x$ & $x$ & $\begin{array}{l}\text { A 24-HDR preceded by a qualitative } 1 \mathrm{~d} \text { food } \\
\text { record has been found to be valid for } \\
\text { generating estimates of children's food } \\
\text { intake for the purpose of group } \\
\text { comparisong } \\
\text { Test for validity was not conducted in } \\
\text { European population }\end{array}$ & No details $\uparrow$ & \\
\hline IDEFICS ${ }^{(39,40,79)}$ & $\begin{array}{l}\text { Prospective } \\
\quad \text { chort study } \\
\text { with an } \\
\text { embedded } \\
\text { intervention }\end{array}$ & $\begin{array}{l}\text { Children }(n \\
16224) \\
2-9 \text { years }\end{array}$ & $\begin{array}{l}8 \text { (Belgium, Cyprus, Estonia, } \\
\text { Germany Hungary, Italy, } \\
\text { Spain, Sweden) }\end{array}$ & $\begin{array}{l}\text { CEHQ-FFQ } \ddagger \\
\text { SACINA 24-HDR } \neq\end{array}$ & $X^{(40,53,101,112-114)}$ & $x$ & 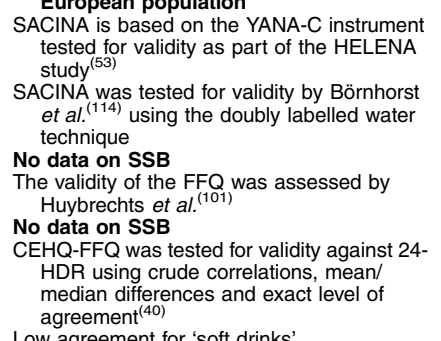 & $\begin{array}{l}\text { No fixed interval } \\
\text { CEHQ-FFQ provides reproducible estimates } \\
\text { of food group intake }{ }^{(112)}\end{array}$ & $\checkmark$ \\
\hline I.Family Project ${ }^{(6,69,70)}$ & $\begin{array}{l}\text { Prospective } \\
\text { cohort study } \\
\text { (successor of } \\
\text { the IDEFICS } \\
\text { study) }\end{array}$ & $\begin{array}{l}\text { Children } \\
(n>9000 \\
\text { children of } \\
\text { IDEFICs study } \\
\text { and their } \\
\text { siblings }) \\
2-11 \text { years }\end{array}$ & $\begin{array}{l}8 \text { (Belgium, Cyprus, Estonia, } \\
\text { Germany Hungary, Italy, } \\
\text { Spain, Sweden) }\end{array}$ & $\begin{array}{l}\text { A diet questionnaire } \\
\text { (FFQ) was included } \\
\text { as part of the } \\
\text { Children's } \\
\text { Questionnaire } \\
\text { Online 24-HDR } \\
\text { (SACANA) }\end{array}$ & $\mathrm{x}$ & $\mathrm{x}$ & $\begin{array}{l}\text { Low agreement for 'soft drinks' } \\
\text { Instruments are similar to those used and } \\
\text { tested for validity as part of the IDEFICS } \\
\text { project }\end{array}$ & No details $\dagger$ & \\
\hline ToyBox $^{(80-90)}$ & $\begin{array}{l}\text { Intervention } \\
\text { multifactorial } \\
\text { study }\end{array}$ & $\begin{array}{l}\text { Children }(n 7056) \\
\quad \text { (providing data } \\
\text { at baseline) } \\
3.5-5.5 \text { years }\end{array}$ & $\begin{array}{c}6 \text { (Belgium, Bulgaria, Germany, } \\
\text { Greece, Poland, Spain) }\end{array}$ & Children's FFQł & $X^{(100)}$ & $\mathrm{x}$ & $\begin{array}{l}\text { The children's questionnaire is based on a } \\
\text { FFQ previously tested for validitity and } \\
\text { developed by Huybrechts et al. } \\
\text { Tesoos } \\
\text { Teed for validity by comparison with } 3 \mathrm{~d} \text { diet } \\
\text { record using crude and de-attenuated } \\
\text { correlations, mean/median differences and } \\
\text { exact level of agreement } \\
\text { Moderate to good agreement for 'sugared } \\
\text { drinks' }\end{array}$ & $\begin{array}{l}\text { Interval: at least } 5 \text { weeks } \\
\text { FFQ provides reproducible estimates of food } \\
\text { group intake }\end{array}$ & $s$ \\
\hline
\end{tabular}

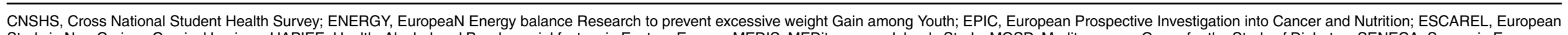

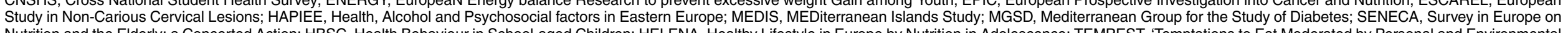

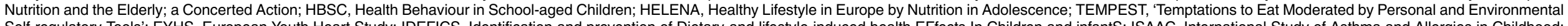

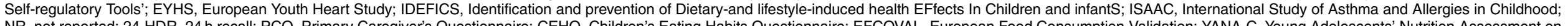

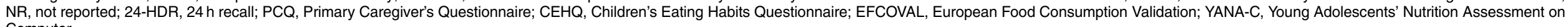
Computer.

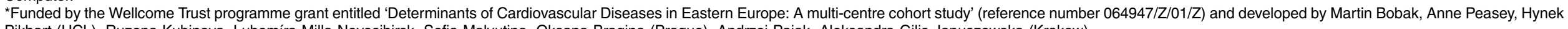
Pikhart (UCL), Ruzena Kubinova, Lubomíra Milla Novosibirsk, Sofia Malyutina, Oksana Bragina (Prague), Andrzej Pajak, Aleksandra Gilis-Januszewska (Krakow).

†Validity or reproducibility of the instrument was not reported in the article and no reference to validation or reproducibility studies was provided.

$\S$ 'Other beverages' includes everything except milk, alcoholic beverages, tea and coffee. 


\section{Validation}

From the studies that were tested for validity or reproducibility and fulfilled the first criterion (Table 1), validity and reliability of FFQ was assessed using $\mathrm{FFQ}^{(105)}$, food records $^{(54,97,100,104)}, 24-\mathrm{HDR}^{(40,54)}$ or interviews ${ }^{(53,98)}$ as reference methods. In eleven studies, validity was assessed by crude correlations $(n 7)^{(40,52-54,97,100,104)}$, energyadjusted correlations $(n 1)^{(105)}$, de-attenuated correlation coefficients $(n 2)^{(40,100)}$, mean or median differences in SSB consumption $(n 7)^{(40,52-54,97,100,105)}$, exact level of agreement of SSB consumption $(n 8)^{(40,53,54,97,100,104,105)}$, Bland-Altman plots $(n 4)^{(40,53,54,105)}$, intraclass correlation coefficients $^{(98)}$ or weighted kappa $(n 2)^{(54,100)}$ between the FFQ and reference instrument. In seven studies, reliability of SSB consumption was assessed by correlations $(n 5)^{(54,83,97,100,112)}$, mean/median differences $(n 3)^{(54,100,112)}$, weighted kappa $\left(\begin{array}{ll}n & 2\end{array}\right)^{(97,112)}$ or intraclass correlation coefficients $^{(98)}$ between subsequent administrations of the FFQ. Details on the validation and/or reproducibility are provided in Table 1 and, where available, extracted results for the statistical assessments are provided in the online supplementary material, Supplemental Table 2.

Validation data specifically on SSB were available for only six instruments, three among adolescents, the HBSC FFQ, HELENA-DIAT and HELENA FFQ, and three among children, the ENERGY Children's Questionnaire, IDEFICS FFQ and ToyBox Children's Questionnaire. The Food4Me FFQ, for use among adult populations, provided validation data only for 'Other beverages' grouped together, described as including all beverages except milk, alcoholic beverages, tea and coffee ${ }^{(104)}$ and including fruit juices, carbonated beverages and squash ${ }^{(105)}$. These instruments are summarised in Table 2.

Although data were not specific to SSB, the Food4Me FFQ had moderate agreement (0.4-0.6) for 'other beverages' with a $4 \mathrm{~d}$ diet record using Spearman's crude correlation $(r=0 \cdot 66)^{(104)}$ and good agreement $(>0 \cdot 6)$ with the EPIC-Norfolk FFQ using energy-adjusted coefficients $(r=0.79)^{(105)}$. In terms of instruments for adolescents, the HBSC FFQ tested for validity against a $7 \mathrm{~d}$ diet record had moderate agreement for 'soft drinks' using Spearman's crude correlation $(r=0 \cdot 46)$. HELENA-DIAT had moderate to good agreement with a $1 \mathrm{~d}$ food record $(r=0.42)$ and 24-HDR $(r=0.65)^{(52)}$, and the HELENA FFQ had good agreement $(r=0.79)$ when tested for validity against four $24-\mathrm{HDR}^{(54)}$. In terms of instruments to be used among children, the construct validity of the ENERGY questionnaire was tested, with moderate (55\%) exact level of agreement for 'soft drinks' between the self-completed questionnaire compared with the questionnaire completed by interview ${ }^{(98)}$. The ToyBox instrument had moderate to good agreement with a $3 \mathrm{~d}$ diet record for 'sugared drinks' $(r=0.57)^{(100)}$, while the IDEFICS CEHQ-FFQ tested for validity against a 24 -HDR had low agreement $(<0 \cdot 4)$ for 'soft drinks' using Pearson's crude correlations among children aged $<6$ years $(r=0 \cdot 14)$ and $6-9$ years $(r=0 \cdot 21)^{(113)}$ (see online supplementary material, Supplemental Table 2).

\section{FFQ}

Table 3 summarises the characteristics of the identified FFQ. These instruments are already described in detail as part of the concurrent review on F\&V intake ${ }^{(37)}$, with the exception of the FFQ used by Cinar and Murtomaa ${ }^{(76)}$ and Kolarzyk et al. ${ }^{(107)}$. Therefore, the results focus on aspects which are specific to the assessment of SSB; that is, definitions and portion measurement, of which there were notable differences between the instruments identified. FFQ were used to assess dietary intake, identify determinants of dietary intake or test diet-disease associations and identify disease risk factors.

\section{Range of items and definitions}

SSB were referred to as 'soft drinks' (HELENA, Finbalt Health Monitor, ENERGY Parent Questionnaire, CNSHS and MEDIS), 'soft drinks with sugar' (Finnish FFQ of the Finnish and Russian Karelia project, EYHS), juice or soft drinks' (Russian FFQ of the Finnish and Russian Karelia project), 'fizzy drinks' (ISAAC, HAPIEE, ENERGY Children's Questionnaire), 'fizzy soft drinks' (Food4Me), 'carbonated drinks (Fanta, Sprite, Coke, Pepsi)' (Szczepanska et $a l{ }^{(72)}$ ), sweet drinks' (Kolarzyk et al. ${ }^{(107)}$ ) and 'ColaCola, Pepsi or other sugary drinks' (MGSD). Where two items referred to SSB on an FFQ, typically one referred to soft drinks, and another referred to squashes or cordials (MGSD, Food4Me) or pre-packed juice (ToyBox).

Few FFQ distinguished between pure fruit juice, and cordials or squashes, with the exception of the ENERGY and Food4Me studies. Some FFQ contained an item that captured intake of a sugarless or low-calorie equivalent (EHYS, HAPIEE, IDEFICS, I.Family, Food4Me, Finnish and Russian Karelia study, and Larsson et al. $\left.{ }^{(71)}\right)$.

\section{Portion size}

Several FFQ assessed the frequency of consumption only and did not record portion size ${ }^{(60,63,64,67,71-73,76,107,110)}$. Of the semi-quantitative FFQ that did assess portion size, many did so in-line using a standard measure and asking participants to specify the number of glasses of SSB consumed $^{(51,54,58,62,73,82)}$, in some cases specifying volume. The MGSD FFQ gave a standard portion as $300 \mathrm{ml}$ or 1 can, whereas in the HAPIEE FFQ this was $2 \mathrm{dl}$. The EHYS FFQ informed participants that one glass approximated to 1 small glass bottle or 2 glasses approximated to a $1 / 2$ litre bottle.

The ENERGY and ToyBox children's questionnaires provided the greatest detail on portion sizes. The former questionnaire asked participants to report the number of glasses or small bottles, cans and/or bottles, and specified volumes for each. The ToyBox questionnaire asked participants to select the average portion size ranging from 
' $100 \mathrm{ml}$ or less' to ' $1000 \mathrm{ml}$ or more', and provided the volumes of typical containers. As part of the ToyBox FFQ, a photographic food guide was also provided to assist with portion size estimation. The Food4Me FFQ asked participants to select from a range of photographs which were linked electronically to portion sizes (in grams).

\section{Dietary recalls}

The characteristics of the identified 24-HDR are summarised in Table 4. The majority of the 24-HDR were used to determine estimates of dietary intake, comparing estimates across regions or over time. These instruments are already described in detail as part of the concurrent review on $\mathrm{F} \& \mathrm{~V}$ intake ${ }^{(37)}$; therefore only details on portion measurement are reported here.

On the ENERGY 24-HDR, participants could select $200 \mathrm{ml}, 350 \mathrm{ml}$ or $500 \mathrm{ml}$ by way of selecting a glass or small bottle, a can or a large bottle, respectively ${ }^{(51)}$. Portion size was also assessed using the HELENA-DIAT, SACINA and EPIC-SOFT instruments. EPIC-SOFT used six quantification methods including photographs and standard measures, both of which were used by the HELENADIAT tool. The IDEFICS SACINA tool measured SSB portion by glass using photographs of six different glass sizes. The EYHS 24-HDR interview was accompanied by different-sized drinking glasses and photographs to aid portion estimation.

\section{Diet records/diet diaries}

Only one diet record was identified, the self-completed $3 \mathrm{~d}$ estimated record which was used in the SENECA study. This instrument is already described in detail in the concurrent review of instruments to assess F\&V intake ${ }^{(37)}$. The purpose of the study was to examine cross-cultural differences in nutrition and lifestyle factors ${ }^{(43)}$ and crosscultural variations and changes in intake over time ${ }^{(123)}$. The population sampled was adults aged $70-75$ years. The $3 \mathrm{~d}$ record was used in conjunction with a frequency checklist of foods that was adapted to local food customs and the order in which they typically appear, and used during the follow-up interview to verify the record. For example, SSB were listed on the Dutch checklist as 'lemonades with sugar, ${ }^{(42,102)}$.

\section{Discussion}

The aim of the current review was to identify the methods used to assess intake of SSB in pan-European studies. The main dietary assessment methods were the FFQ, 24-HDR and diet record/diet diary. The review identified twelve instruments to assess intake of SSB in children or adolescents in the age range of 2-12 years, seven among children and six among adolescents. Fourteen instruments were identified that assessed intake of SSB among adults, three of which assessed parents or caregivers. Of the identified FFQ, thirteen could be used among adult populations, six among adolescents and six among children. A few key differences were identified between the methods, some of which have been reported previously $^{(124,125)}$. For example, in terms of the FFQ, differences included: the definition of SSB used; the number and range of frequency categories; the time period covered by the FFQ; and the approach to determining portion size. Such differences, in particular, how SSB are defined, should be resolved if future instruments are to be standardised across Europe.

The present review is the first to systematically identify and describe instruments used to assess intake of SSB in pan-European studies. Although a growing body of research points to a possible association between the consumption of SSB and obesity, there is currently a lack of standardised instruments available for use in panEuropean studies when measuring and monitoring the intake of SSB. A large number of instruments were identified through the review. Similar to the approach used for the concurrent review of methods to assess F\&V intake ${ }^{(37)}$, to reduce the number of instruments, identify potential instruments for use in future pan-European studies measuring SSB intake and determine those to be included in the DEDIPAC toolbox, two selection criteria were applied: (i) the instrument was tested for validity and/or reproducibility; and (ii) the instrument was used in more than two countries simultaneously which represented a range of European regions.

According to these selection criteria, five instruments were considered appropriate to assess SSB among adults in pan-European studies, namely those used by the EPIC, Food4Me, SENECA, ToyBox and ENERGY studies. However, only the Food4Me FFQ was tested for validity for intake of SSB (but grouped together with other drinks as 'other beverages') using $4 \mathrm{~d}$ diet records ${ }^{(104)}$. The HELENA-DIAT ${ }^{(53)}$, HELENA online $\mathrm{FFQ}^{(54)}$ and HBSC $\mathrm{FFQ}^{(97)}$ appeared appropriate to assess intake among adolescents and demonstrated moderate to good agreement with $1 \mathrm{~d}$ records and 24-HDR, four 24-HDR and $7 \mathrm{~d}$ diet records, respectively. Only three of the four instruments selected to be used among children were tested for validity for SSB (IDEFICS FFQ, ENERGY and ToyBox $)^{(98,100,113)}$ and the ENERGY questionnaire was tested only for construct validity. The IDEFICS and ToyBox instruments demonstrated low agreement with 24-HDR and moderate to good agreement with a $3 \mathrm{~d}$ diet record, respectively. It is important to note that these instruments were all tested for validity against other self-report (and potentially error-prone) methods, namely FFQ, food records, 24-HDR or interviews.

The two selection criteria, along with the summary of validation data, indicate the methods which may be appropriate to use in pan-European studies. However, as already outlined in the review of methods to assess F\&V 
Table 2 Summary of the selected instruments which were tested for validity ( $n$ 7) for assessment of sugar-sweetened beverages (SSB): design, age group, countries, mode of administration, definition of SSB used and portion estimation

\begin{tabular}{|c|c|c|c|c|c|c|}
\hline Study/instrument & Design & Age group & Countries & Mode & Definition & $\begin{array}{l}\text { Portion } \\
\text { estimation }\end{array}$ \\
\hline $\begin{array}{l}\text { Adults } \\
\text { Food4Me } \text { (103-105) }^{(1002} \mathrm{FQ} \\
\text { Web-based FFQ }\end{array}$ & Randomised controlled trial & $17-79$ years & $\begin{array}{l}7 \text { (Ireland, Netherlands, Spain, Greece, UK, } \\
\text { Poland, Germany) }\end{array}$ & Self-admin. & $\begin{array}{l}\text { 'Fizzy soft drinks, e.g. coca cola/lemonade' } \\
\text { 'Low-calorie/diet fizzy soft drinks' } \\
\text { 'Fruit squash/cordial/nectar' }\end{array}$ & $\mathrm{x}$ \\
\hline $\begin{array}{l}\text { Adolescents } \\
\text { HBSC (67) } \\
\text { FFQ }\end{array}$ & Cross-sectional & $\begin{array}{l}\text { 11-, 13- and } \\
15 \text {-year-olds }\end{array}$ & $\begin{array}{l}37 \text { (England, Norway, Macedonia, Iceland, } \\
\text { Netherlands, Portugal, Wales, Italy, Sweden, } \\
\text { Latvia, Switzerland, Denmark, Estonia, } \\
\text { Scotland, Slovenia, Ukraine, Belgium, Finland, } \\
\text { Greece, Croatia, Hungary, Lithuania, Poland, } \\
\text { Germany, Greenland, Russia, Armenia, Austria, } \\
\text { Belgium, Spain, France, Romania, Turkey, } \\
\text { Czech Republic, Ireland, Luxembourg, Slovakia) }\end{array}$ & Self-admin. & $\begin{array}{l}\text { 'Sweetened soft drinks (cola or other soft drinks that } \\
\text { contain sugar)' }\end{array}$ & \\
\hline $\begin{array}{l}\text { HELENA }{ }^{(44,45,52-55,68)} \\
24-H D R \\
\text { HELENA-DIAT }\end{array}$ & Cross-sectional & $13-17$ years & $\begin{array}{l}8 \text { (Greece, Germany, Belgium, France, Italy, } \\
\text { Sweden, Austria, Spain) }\end{array}$ & $\begin{array}{l}\text { Self-admin. } \\
\text { Computerised }\end{array}$ & $\begin{array}{l}\text { 'Regular soft drinks' } \\
\text { 'Diet soft drinks' }\end{array}$ & $x$ \\
\hline $\begin{array}{l}\text { HELENA } \\
\text { Online FFQ }\end{array}$ & & $13-17$ years & 5 (Austria, Belgium, Greece, Sweden, Germany) & Self-admin. & - & $x$ \\
\hline $\begin{array}{l}\text { Children } \\
\text { IDEFICS } \\
\text { CEHQ-FF,*40,79) }\end{array}$ & $\begin{array}{l}\text { Prospective cohort study with } \\
\text { an embedded intervention }\end{array}$ & $2-9$ years & $\begin{array}{l}8 \text { (Belgium, Cyprus, Estonia, Germany Hungary, } \\
\text { Italy, Spain, Sweden) }\end{array}$ & Self-admin. (parents) & $\begin{array}{l}\text { 'Sweetened drinks including sports drinks, bottled or } \\
\text { canned tea, syrup-based drinks and similar' } \\
\text { 'Diet coke or diet soft drinks' }\end{array}$ & \\
\hline $\begin{array}{l}\text { ENERGY'(51,77) } \\
\text { Children's FFQ } \\
\text { ToyBox }{ }^{(80-90)} \\
\text { Children's FFQ* }\end{array}$ & $\begin{array}{l}\text { Cross-sectional } \\
\text { Intervention multifactorial study }\end{array}$ & $\begin{array}{l}10-12 \text { years } \\
3.5-5.5 \text { years }\end{array}$ & $\begin{array}{l}7 \text { (Belgium, Greece, Hungary, Netherlands, } \\
\text { Norway, Slovenia, Spain) } \\
6 \text { (Belgium, Bulgaria, Germany, Greece, Poland, } \\
\text { Spain) }\end{array}$ & $\begin{array}{l}\text { Self-admin. } \\
\text { Self-admin. }\end{array}$ & $\begin{array}{l}\text { 'Fizzy drinks or fruit squash', } \\
\text { 'Specified that this was: 'NOT diet drinks and fruit juice' } \\
\text { 'Sugared beverages (Coca-Cola, Pepsi, Fanta, Sprite, } \\
\text { Nestea)' } \\
\text { 'Fruit juice, pre-packed/ bottled' }\end{array}$ & $\begin{array}{l}x \\
x\end{array}$ \\
\hline
\end{tabular}

HBSC, Health Behaviour in School-aged Children; HELENA, Healthy Lifestyle in Europe by Nutrition in Adolescence; 24-HDR, 24h recall; IDEFICS, Identification and prevention of Dietary- and lifestyle-induced health effects In Children and infants; CEHQ, Children's Eating Habits Questionnaire; ENERGY, EuropeaN Energy balance Research to prevent excessive weight Gain among Youth; self-admin., self-administered.
${ }^{*}$ Original instrument obtained for review. 


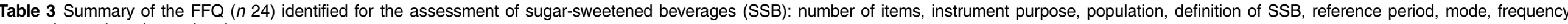
categories and portion estimation

\begin{tabular}{|c|c|c|c|c|c|c|c|c|}
\hline Study & Type/number of items & Purpose & Population & Definition & Reference period & Mode & Frequency categories & Portion estimated? (yes/no) \\
\hline \multirow{2}{*}{$\begin{array}{l}\text { Adults } \\
\text { CNSHS } \\
(56,57)\end{array}$} & & & & & & & & \\
\hline & $\begin{array}{l}\text { Non-quantitative } \\
\text { General questionnaire } \\
\text { One item on SSB }\end{array}$ & $\begin{array}{l}\text { Test association between food } \\
\text { patterns and living } \\
\text { arrangements } \\
\text { Test association between diet and } \\
\text { stress/depressive symptoms }{ }^{(57)}\end{array}$ & $\begin{array}{l}\text { Adults/students } \\
\text { Age range NR }\end{array}$ & 'Soft drinks' & NR & Self-admin. & $\begin{array}{l}5 \text { categories, ranging from 'several times } \\
\text { a day' to ' } 1-4 \text { times a month', and } \\
\text { 'never' }\end{array}$ & No \\
\hline ENERGY(51)^ Adults' FFQ & $\begin{array}{l}\text { Semi-quantitative } \\
\text { General questionnaire } \\
\text { One item on SSB }\end{array}$ & $\begin{array}{l}\text { Determine prevalence of EBRB } \\
\text { Identify personal, family and school } \\
\text { environmental correlates of } \\
\text { EBRB }\end{array}$ & $\begin{array}{l}\text { Adults/caregivers } \\
\text { Age range NR }\end{array}$ & $\begin{array}{l}\text { 'Soft drinks' defined as: 'Fizzy drinks } \\
\text { and fruit squash but NOT diet } \\
\text { drinks and fruit juice' } \\
\text { Provided examples }\end{array}$ & $\begin{array}{l}\text { Previous week } \\
\text { Usual consumption on } \\
\text { a day on which } \\
\text { SSB consumed }\end{array}$ & Self-admin. & $\begin{array}{l}7 \text { categories per week, ranging from } \\
\text { 'never', '1 portition or less per week' to } \\
\text { '5 or more portions per day' } \\
6 \text { categories per day, ranging from 'none', } \\
\text { '1 glasss/small bottle' to '5 or more } \\
\text { glasses/bottles' }\end{array}$ & $\begin{array}{l}\text { Yes } \\
\text { Assessed in-line } \\
\text { Subjectc can select the number of } \\
\text { glasses/ small cartons }(250 \mathrm{ml}) \\
\text { and regular cartons }(330 \mathrm{ml}) \\
\text { drank on a day of consumption }\end{array}$ \\
\hline ESCAREL ${ }^{(110)}$ & $\begin{array}{l}\text { Non-quantitative } \\
\text { Five-item FFQ } \\
\text { Two items on SSB }\end{array}$ & $\begin{array}{l}\text { Assess the prevalence of tooth wear } \\
\text { on buccal/facial and lingual/ } \\
\text { palatal tooth surfaces } \\
\text { Identify related risk factors (i.e. } \\
\text { fresh fruit and juice intake) }\end{array}$ & $\begin{array}{l}\text { Adults } \\
18-35 \text { years }\end{array}$ & $\begin{array}{l}\text { 'Soft drinks, i.e. cola beverages, } \\
\text { Sprite, lemonade, Fanta, iced tea, } \\
\text { etc.' } \\
\text { 'Isotonic drinks/energy drinks, e.g. } \\
\text { Isostar, Powerade, Perform, Red- } \\
\text { bull, Red Horse, etc.' }\end{array}$ & Not stated & Self-admin. & $\begin{array}{l}4 \text { categories: 'often', 'rarely', 'never', } \\
\text { 'don't know' } \\
\text { For items ranked as 'often', a choice of } 5 \\
\text { categories ranging from 'more than } 3 \\
\text { times per week to 'less than once per } \\
\text { week' could be selected }\end{array}$ & No \\
\hline Finbalt Health Monitor ${ }^{(60) *}$ & $\begin{array}{l}\text { Non-quantitative } \\
\text { Sixteen-item FFQ } \\
\text { One item on SSB }\end{array}$ & $\begin{array}{l}\text { Assess gender differences in F\&V } \\
\text { consumption }\end{array}$ & $\begin{array}{l}\text { Adults } \\
20-64 \text { years }\end{array}$ & 'Soft drinks' & Previous week & Self-admin. & $\begin{array}{l}4 \text { categories: 'never', ' } 1-2 \text { days', ' } 3- \\
5 \text { days' and ' } 6-7 \text { days' }\end{array}$ & No \\
\hline $\begin{array}{l}\text { Finnish and Russian Karelia } \\
\text { study }^{(65) \star}(2002 \text { survey) }\end{array}$ & $\begin{array}{l}\text { Non-quantitative } \\
\text { Forty-three-item Finnish } \\
\text { FFQ (FINRISK), two } \\
\text { items on SSB } \\
\text { Twenty-item Russian } \\
\text { FFQ, one item on } \\
\text { SSB }\end{array}$ & $\begin{array}{l}\text { Determine socio-economic } \\
\text { differences in the consumption of } \\
\text { vegetables, fruit and berries in } \\
\text { two regions }\end{array}$ & $\begin{array}{l}\text { Adults } \\
25-64 \text { years }\end{array}$ & $\begin{array}{l}\text { Finnish FFQ: } \\
\text { 'Soft drinks with sugar (e.g. cola etc)' } \\
\text { 'Diet soft drinks (e.g. Funlight, Pepsi } \\
\text { Max, Light-Cola)' } \\
\text { Russian FFQ: } \\
\text { 'Juices or soft drinks' }\end{array}$ & 12 months & Self-admin. & $\begin{array}{l}6 \text { categories, ranging from 'less than } \\
\text { once a month' to 'daily or more often' }\end{array}$ & No \\
\hline Food4Me ${ }^{(103-105)}$ & $\begin{array}{l}\text { Semi-quantitative, web- } \\
\text { based, } 157 \text {-item FFQ }\end{array}$ & $\begin{array}{l}\text { Determine impact of personalised } \\
\text { dietary advice on eating patterns } \\
\text { and health outcomes }\end{array}$ & $\begin{array}{l}\text { Adults } \\
18-79 \text { years }\end{array}$ & $\begin{array}{l}\text { Under 'Drinks': } \\
\text { 'Fizzy soft drinks, e.g. coca cola/ } \\
\text { lemonade' } \\
\text { 'ow-calorie/diet fizzy soft drinks' } \\
\text { 'Fruit squash/cordia//nectar' }\end{array}$ & Previous month & Self-admin. & $\begin{array}{l}9 \text { categories, ranging from 'never or less } \\
\text { than once a month' to ' } 5-6 \text { times } \\
\text { per day' and '>6 times per day' }\end{array}$ & $\begin{array}{l}\text { Yes } \\
\text { Three photographs representing } \\
\text { small, medium and large portions } \\
\text { Participants could select one of the } \\
\text { following options: 'very, small', } \\
\text { 'small', 'small/medium,', 'medium' } \\
\text { 'medium/large,', 'large' or 'very } \\
\text { large', which were linked } \\
\text { electronically to portion sizes (in } \\
\text { grams) }\end{array}$ \\
\hline HAPIEE $^{(58) \star}$ & $\begin{array}{l}\text { Semi-quantitative } \\
\text { Items: CZech }=136, \\
\text { Russian }=147, \\
\text { Polish }=148 \\
\text { Three items on SSB }\end{array}$ & $\begin{array}{l}\text { Test association between socio- } \\
\text { economic indicators and } \text { diet }^{(115)}\end{array}$ & $\begin{array}{l}\text { Adults } \\
45-69 \text { years }\end{array}$ & $\begin{array}{l}\text { As per generic FFQ } \\
\text { 'Fizzy drink' } \\
\text { 'Squash' } \\
\text { 'Diet/low-calorie fizzy drinks' }\end{array}$ & Previous 3 months & $\begin{array}{l}\text { Interview (Russia } \\
\text { \& Poland) } \\
\text { Self-admin. } \\
\text { (Czech } \\
\text { Republic) }\end{array}$ & $\begin{array}{l}9 \text { categories, ranging from 'never' to ' } 6 \text { or } \\
\text { more times per day' } \\
\text { Open-ended section where subject could } \\
\text { add any further foods not listed }\end{array}$ & $\begin{array}{l}\text { Yes } \\
\text { Assessed in-line } \\
\text { A country-specific portion size for } \\
\text { each food was specified } \\
\text { Participants were asked how often, } \\
\text { on average, they had consumed } \\
\text { a 'medium serving' of the items - } \\
\text { defined as } 2 \text { dl or } 1 \text { tablespoon } \\
\text { (squash) }\end{array}$ \\
\hline I.Family Project ${ }^{(66,69)}$ & $\begin{array}{l}\text { Non-quantitative } \\
\text { Sixty-item FFQ } \\
\text { Four items on SSB }\end{array}$ & $\begin{array}{l}\text { Assess determinants of eating } \\
\text { behaviour }\end{array}$ & $\begin{array}{l}\text { Adults/parents } \\
\text { Age range not } \\
\text { determined }\end{array}$ & $\begin{array}{l}\text { 'Carbonated sugar sweetened drinks } \\
\text { (e.g. Coca-Ccola, Fanta, non- } \\
\text { alcoholic beer, etc.)' } \\
\text { 'Diet carbonated drinks (e.g. diet } \\
\text { cola, etc.)' } \\
\text { 'Sugar-sweetened drinks, not } \\
\text { carbonated (e.g. bottled ice tea, } \\
\text { syrup-based drinks and similar, } \\
\text { fruit juices with less than } 100 \% \\
\text { fruit, sports drinks, non-alcoholic } \\
\text { wine, etc.)' } \\
\text { 'Artificially sweetened drinks, not } \\
\text { carbonated (e.g. diet ice tea, diet } \\
\text { fruit syrup, diet sports drinks, } \\
\text { etc.)' }\end{array}$ & $\begin{array}{l}\text { Typical week over the } \\
\text { previous month }\end{array}$ & Self-admin. & $\begin{array}{l}7 \text { categories, ranging from 'never/less } \\
\text { than once a week' to ' } 4 \text { or more times } \\
\text { per day' }\end{array}$ & No \\
\hline Kolarzyk et al. ${ }^{(107) *}$ & $\begin{array}{l}\text { Non-quantitative } \\
\text { Thirty-nine-item FFQ } \\
\text { One item on SSB }\end{array}$ & $\begin{array}{l}\text { Examine the food choices and } \\
\text { determine the prevalence of } \\
\text { underweight, overweight and } \\
\text { obesity }\end{array}$ & $\begin{array}{l}\text { Adults/students } \\
\text { Age range NR }\end{array}$ & $\begin{array}{l}\text { Local examples provided } \\
\text { 'Sweet drinks' }\end{array}$ & Previous month & Self-admin. & $\begin{array}{l}7 \text { categories, ranging from 'not eaten at } \\
\text { all' to 'eaten every day' }\end{array}$ & No \\
\hline
\end{tabular}


Table 3 Continued

\begin{tabular}{|c|c|c|c|c|c|c|c|c|}
\hline Study & Type/number of items & Purpose & Population & Definition & Reference period & Mode & Frequency categories & Portion estimated? (yes/no) \\
\hline MEDIS study ${ }^{(61,95)}$ & $\begin{array}{l}\text { Semi-quantitative } \\
\text { Total number of items } \\
\text { unknown }\end{array}$ & $\begin{array}{l}\text { Test association between energy- } \\
\text { generating nutrients and obesity }\end{array}$ & $\begin{array}{l}\text { Adults/elderly } \\
65-80+\text { years }\end{array}$ & 'Soft drinks' & NR & NR & $\begin{array}{l}\text { Frequency assessed on a daily, weekly or } \\
\text { monthly basis }\end{array}$ & No \\
\hline $\operatorname{MGSD}^{(62) *}$ & $\begin{array}{l}\text { Dietary history method } \\
\text { using a seventy-eight- } \\
\text { item FFQ } \\
\text { One item on SSB }\end{array}$ & $\begin{array}{l}\text { Compare the nutritional habits } \\
\text { among six Mediterranean } \\
\text { countries and with official } \\
\text { recommendations }\end{array}$ & $\begin{array}{l}\text { Adults } \\
35-60 \text { years }\end{array}$ & $\begin{array}{l}\text { 'Coca-Cola, Pepsi or other sugary } \\
\text { drinks' }\end{array}$ & NR & $\begin{array}{l}\text { Interview } \\
\text { administered } \\
\text { face-to-face }\end{array}$ & $\begin{array}{l}\text { Enter number per day or per week for } \\
\text { pre-coded items } \\
\text { Open-ended section structured by } 7 \\
\text { meals, where participant enters the } \\
\text { time, description, quantity and } \\
\text { whether food was eaten at home or in } \\
\text { a restaurant }\end{array}$ & $\begin{array}{l}\text { Assessed in-line } \\
300 \mathrm{ml}, 1 \text { can } \\
\text { Assessed separately } \\
\text { Household measures }\end{array}$ \\
\hline $\begin{array}{l}\text { ToyBox }(82,83) \star \text { Caregiver's } \\
\text { Questionnaire }\end{array}$ & $\begin{array}{l}\text { Semi-quantitative } \\
\text { Forty-four-item FFQ } \\
\text { Two items on SSB }\end{array}$ & $\begin{array}{l}\text { Measure the effectiveness of an } \\
\text { intervention to prevent obesity }\end{array}$ & $\begin{array}{l}\text { Adults/parents or } \\
\text { guardians } \\
\text { Age range NR }\end{array}$ & $\begin{array}{l}\text { 'Sugared beverages (soda drinks } \\
\text { like cola, lemonade, ice tea)' } \\
\text { (defined as: 'all sugared or sweet- } \\
\text { flavoured beverages, carbonated } \\
\text { or not, plain or light e.g. Cola and } \\
\text { Cola light/zero, Ice Tea, } 7 \text {-up, } \\
\text { Pepsi, Fanta, Fanta non- } \\
\text { carbonated, Sprite, Orangina, } \\
\text { etc.)'. } \\
\text { 'Fruit juice, pre-packed/bottled } \\
\text { (100\%, nectar etc.)' (defined as } \\
\text { 'all fruit juice-based products } \\
\text { including } 100 \% \text { \%resh juice } \\
\text { bottled or in paper-pack, } 30 \% \\
\text { fruit juice with added sugar } \\
\text { (nectarl, sports drinks, } \\
\text { smoothies, canned juices, e.g. } \\
\text { Life, Tropicana, lemonade, } \\
\text { Lucozade') }\end{array}$ & NR & Self-admin. & $\begin{array}{l}7 \text { categories, ranging from ' } 1-3 \text { days per } \\
\text { month' to 'every day' }\end{array}$ & $\begin{array}{l}\text { Yes } \\
\text { Assessed in-line } \\
\text { Portion sizes provided: } \\
1 \text { cup }=250 \mathrm{ml} ; 1 \mathrm{can}=330 \mathrm{ml} \text {, } \\
1 \text { small plastic bottle }=500 \mathrm{ml} ; \\
1 \text { glass lemonade }=250 \mathrm{ml}\end{array}$ \\
\hline $\begin{array}{l}\text { Adolescents } \\
\text { HBSC 2009/10 survey }{ }^{(41,67) \star} \\
\text { FFQ }\end{array}$ & $\begin{array}{l}\text { Non-quantitative } \\
\text { Seven-item FFQ, four } \\
\text { mandatory items } \\
\text { One item on SSB }\end{array}$ & $\begin{array}{l}\text { Determine health and health } \\
\text { behaviours and the factors that } \\
\text { influence them } \\
\text { Investigate influence of } \\
\text { chronological period of data } \\
\text { collection on dietary intake }{ }^{(67)}\end{array}$ & $\begin{array}{l}\text { Adolescents } \\
11-, 13-\text { and } 15- \\
\text { year-olds }\end{array}$ & $\begin{array}{l}\text { 'Sweetened soft drinks (cola or other } \\
\text { soft drinks that contain sugar)' }\end{array}$ & $\begin{array}{l}\text { Habitual intake over } \\
\text { week }\end{array}$ & Self-admin. & $\begin{array}{l}7 \text { categories, ranging from 'never' 'less } \\
\text { than once a week' to 'every day, more } \\
\text { than once' }\end{array}$ & 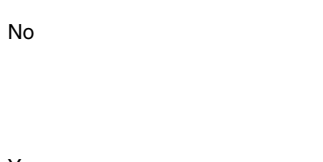 \\
\hline HELENA $^{(54,55)}$ & $\begin{array}{l}\text { Semi-quantitative } \\
137 \text {-item FFQ } \\
\text { Two items on SSB }\end{array}$ & $\begin{array}{l}\text { Assess effectiveness of an } \\
\text { intervention to enhance the } \\
\text { physical activity and diet of } \\
\text { adolescents }\end{array}$ & $\begin{array}{l}\text { Adolescents } \\
13-17 \text { years }\end{array}$ & $\begin{array}{l}\text { 'Regular soft drinks' and 'Diet soft } \\
\text { drinks' listed under the } \\
\text { 'beverages' heading }\end{array}$ & NR & Self-admin. & $\begin{array}{l}\text { Select from typically } 10 \text { frequency } \\
\text { categories, then select frequency of: } \\
\text { units per day', 'units per week' or } \\
\text { 'units during the last } 30 \text { days' }\end{array}$ & $\begin{array}{l}\text { Yes } \\
\text { Assessed in-line } \\
\text { Frequency and portion selected } \\
\text { together for fruit juices; i.e. } 1 \\
\text { glass/2 glass, .., } 10 \text { glasses } \\
\text { Assessed separately } \\
\text { Photos, four portion sizes } \\
\text { (amorphous foods) }\end{array}$ \\
\hline I.Family Project ${ }^{(66,69) \star}$ & $\begin{array}{l}\text { Non-quantitative } \\
\text { Sixty-item FFQ } \\
\text { Four items on SSB }\end{array}$ & $\begin{array}{l}\text { Assess determinants of eating } \\
\text { behaviour }\end{array}$ & $\begin{array}{l}\text { Adolescents } \\
12-17 \text { years }\end{array}$ & $\begin{array}{l}\text { 'Carbonated sugar-sweetened } \\
\text { drinks (e.g. Coca-Cola, Fanta, } \\
\text { non-alcoholic beer, etc.)' } \\
\text { 'Diet carbonated drinks (e.g. diet } \\
\text { cola, etc.).' } \\
\text { 'Sugar-sweetened drinks, not } \\
\text { carbonated (e.g. bottled ice tea, } \\
\text { syrup-based drinks and similar, } \\
\text { fruit juices with less than } 100 \% \\
\text { fruit, sports drinks, non-alcoholic } \\
\text { wine, etc.)' } \\
\text { 'Artificially sweetened drinks, not } \\
\text { carbonated (e.g. diet ice tea, diet } \\
\text { fruit syrup, diet sports drinks, } \\
\text { etc.). } \\
\text { Local examples provided }\end{array}$ & $\begin{array}{l}\text { Typical week over the } \\
\text { previous month }\end{array}$ & Self-admin. & $\begin{array}{l}7 \text { categories, ranging from 'never/less } \\
\text { than once a week' to ' } 4 \text { or more times } \\
\text { per day' }\end{array}$ & No \\
\hline Larsson et al. ${ }^{(71) *}$ & $\begin{array}{l}\text { Non-quantitative } \\
\text { Thirty-three-item FFQ } \\
\text { Two items on SSB }\end{array}$ & $\begin{array}{l}\text { Determine prevalence of } \\
\text { vegetarianism } \\
\text { Compare food habits among } \\
\text { vegetarians and omnivores }\end{array}$ & $\begin{array}{l}\text { Adolescents } \\
\text { Age range NR }\end{array}$ & $\begin{array}{l}\text { 'Regular soda' } \\
\text { 'Light soda' }\end{array}$ & Not stated & Self-admin. & $\begin{array}{l}6 \text { categories, ranging from 'never/rarely' } \\
\text { to 'several times a day'. Subjects also } \\
\text { report for a typical weekday, times } \\
\text { they usually eat and what type of meal } \\
\text { they usually eat at the time }\end{array}$ & No \\
\hline Szczepanska et al..$^{(72) \star}$ & $\begin{array}{l}\text { Non-quantitative } \\
\text { Twelve-item FFQ } \\
\text { One item on SSB }\end{array}$ & Assess and compare dietary habits & $\begin{array}{l}\text { Middle school age } \\
\text { Age range NR }\end{array}$ & $\begin{array}{l}\text { 'Carbonated drinks (Fanta, Sprite, } \\
\text { Coke, Pepsi)' }\end{array}$ & Not stated & Self-admin. & $\begin{array}{l}5 \text { categories, ranging from 'daily', '3-4 } \\
\text { times a week' to 'several times a } \\
\text { month', 'less/occasionally', 'never' }\end{array}$ & No \\
\hline
\end{tabular}




\section{Table 3 Continued}

\begin{tabular}{|c|c|c|c|c|c|c|c|c|}
\hline Study & Type/number of items & Purpose & Population & Definition & Reference period & Mode & Frequency categories & Portion estimated? (yes/no) \\
\hline TEMPEST $^{(73-75) \star}$ & $\begin{array}{l}\text { Semi-quantitative } \\
\text { Five-item FFQ } \\
\text { One item on SSB }\end{array}$ & $\begin{array}{l}\text { Test association of 'subjective peer } \\
\text { norms' with eating intentions and } \\
\text { diet }\end{array}$ & $\begin{array}{l}\text { Adolescents } \\
12-17 \text { years }\end{array}$ & $\begin{array}{l}\text { 'Soft drinks, lemonade or energy } \\
\text { drinks' } \\
\text { Explained that light soft drinks and } \\
\text { mineral water should not be taken } \\
\text { into account for the soft drink } \\
\text { measure }\end{array}$ & Per average day & Self-admin. & $\begin{array}{l}5 \text { categories, ranging from 'less than } 1 \text { ' to } \\
\text { 'more than } 4 \text { ' }\end{array}$ & $\begin{array}{l}\text { Yes } \\
\text { Assessed in-line } \\
\text { Specified 'glass' as the portion }\end{array}$ \\
\hline $\begin{array}{l}\text { Children } \\
\text { Cinar and Murtomaa }{ }^{(76) \star *} \text { Pre- } \\
\text { adolescent FFQ }\end{array}$ & $\begin{array}{l}\text { Non-quantitative } \\
\text { Fourteen-item FFQ } \\
\text { One item on SSB }\end{array}$ & $\begin{array}{l}\text { Determine clustering between } \\
\text { obesity and lifestyle factors in two } \\
\text { countries }\end{array}$ & $\begin{array}{l}\text { Children } \\
10-12 \text { years }\end{array}$ & 'Soft drinks or juice' & Previous week & Self-admin. & $\begin{array}{l}4 \text { categories: '6-7 days', '3-5 days', '1- } \\
2 \text { days' and 'not at all' }\end{array}$ & No \\
\hline $\begin{array}{l}\text { ENERGY }{ }^{(51,77) *} \text { Children's } \\
\text { FFQ }\end{array}$ & $\begin{array}{l}\text { Gemi-quantitative } \\
\text { General questionnaire } \\
\text { One item on SSB }\end{array}$ & $\begin{array}{l}\text { Determine prevalence of EBRB } \\
\text { Identify personal, family and school } \\
\text { environmental correlates of } \\
\text { EBRB }\end{array}$ & $\begin{array}{l}\text { Children } \\
10-12 \text { years }\end{array}$ & $\begin{array}{l}\text { 'Fizzy drinks or fruit squash' } \\
\text { Specified that this was: 'NOT diet } \\
\text { drinks and fruit juice' } \\
\text { Provided examples }\end{array}$ & $\begin{array}{l}\text { Previous week } \\
\text { Usual consumption on } \\
\text { a day on which } \\
\text { SSB consumed }\end{array}$ & Self-admin. & $\begin{array}{l}7 \text { categories per week, ranging from } \\
\text { 'never', } 1 \text { portion or less per week' to } \\
\text { '5 or more portions per day' } \\
6 \text { categories per day, ranging from 'none', } \\
\text { '1 glasss/small bottle' to ' } 5 \text { or more } \\
\text { glassses/bottles' }\end{array}$ & $\begin{array}{l}\text { Yes } \\
\text { Assessed in-line } \\
\text { Subjectc can select number of } \\
\text { glasses/small cartons }(250 \mathrm{ml}) \\
\text { and regular cartons }(330 \mathrm{ml}) \\
\text { drank on a day of consumption }\end{array}$ \\
\hline IDEFICS $^{(39,40,79) \star}$ & $\begin{array}{l}\text { Non-quantitative } \\
\text { Forty-eight-item FFQ } \\
\text { Two items on SSB }\end{array}$ & $\begin{array}{l}\text { Determine the aetiology of } \\
\text { overweight, obesity and related } \\
\text { disorders } \\
\text { Test association between diet and } \\
\text { cardiovascular risk factors }{ }^{1117} \\
\text { Test association between diet and } \\
\text { BMI }\end{array}$ & $\begin{array}{l}\text { Children } \\
2-9 \text { years } \\
\text { (parents or } \\
\text { guardians as } \\
\text { proxies) }\end{array}$ & $\begin{array}{l}\text { 'Sweetened drinks including sports } \\
\text { drinks, bottled or canned tea, } \\
\text { syrup--based drinks and similar' } \\
\text { Local examples given. } \\
\text { 'Diet coke or diet soft drinks' } \\
\text { Local examples given }\end{array}$ & $\begin{array}{l}\text { Typical week over the } \\
\text { previous month }\end{array}$ & Self-admin. & $\begin{array}{l}\text { glassessibotlles } \\
8 \text { categories, ranging from 'never/less } \\
\text { than once a week' to '4 or more times } \\
\text { per day' } \\
\text { I have no idea' was also an option }\end{array}$ & No drank on a day of consumption \\
\hline I.Family Project ${ }^{(66,69) \star}$ & $\begin{array}{l}\text { Non-quantitative } \\
\text { Fifty-nine-item FFQ } \\
\text { Four items on SSB }\end{array}$ & $\begin{array}{l}\text { Assess determinants of eating } \\
\text { behaviour }\end{array}$ & $\begin{array}{l}\text { Children } \\
2-11 \text { years } \\
\text { (parents or } \\
\text { guardians as } \\
\text { proxies) }\end{array}$ & $\begin{array}{l}\text { 'Carbonated sugar sweetened drinks } \\
\text { (e.g. Coca-Cola, Fanta, non- } \\
\text { alcoholic beer, etc.)' } \\
\text { 'Diet carbonated drinks (e.g. diet } \\
\text { cola, etc.)' } \\
\text { 'Sugar-sweetened drinks, not } \\
\text { carbonated (e.g. bottled ice tea, } \\
\text { syrup-based drinks and similar, } \\
\text { fruit juices with less than } 100 \% \\
\text { fruit, sports drinks, non-alcoholic } \\
\text { wine, etc.)' } \\
\text { 'Artificially sweetened drinks, not } \\
\text { carbonated (e.g. diet ice tea, diet } \\
\text { fruit syrup, diet sports drinks, } \\
\text { etc.)' } \\
\text { Local examples provided }\end{array}$ & $\begin{array}{l}\text { Typical week over the } \\
\text { previous month }\end{array}$ & Self-admin. & $\begin{array}{l}7 \text { categories, ranging from 'never/less } \\
\text { than once a week' to '4 or more times } \\
\text { per day' }\end{array}$ & No \\
\hline ISAAC study & $\begin{array}{l}\text { Non-quantitative } \\
\text { General questionnaire } \\
\text { Eight-item FFQ } \\
\text { One item on SSB }\end{array}$ & $\begin{array}{l}\text { Test association between dietary } \\
\text { factors, asthma and allergy }\end{array}$ & $\begin{array}{l}\text { Children } \\
8-12 \text { years } \\
\text { (parents or } \\
\text { guardians as } \\
\text { proxies) }\end{array}$ & 'Fizzy drinks' & Not stated & Self-admin. & $\begin{array}{l}5 \text { categories, ranging from 'never' to } \\
\text { 'once per day or more often' }\end{array}$ & No \\
\hline ToyBox ${ }^{(82,83) \star}$ Children's FFQ & $\begin{array}{l}\text { Semi-quantitative } \\
\text { Forty-four-item FFQ } \\
\text { Two items on SSB }\end{array}$ & $\begin{array}{l}\text { Measure the effectiveness of an } \\
\text { intervention to prevent obesity }\end{array}$ & $\begin{array}{l}\text { Children } \\
3.5-5.5 \text { years } \\
\text { (parents or } \\
\text { guardians as } \\
\text { proxies) }\end{array}$ & $\begin{array}{l}\text { 'Sugared beverages (Coca-Cola, } \\
\text { Pepsi, Fanta, Sprite, Nestea)' } \\
\text { 'Fruit juice, pre-packed/bottled' }\end{array}$ & 12 months & Self-admin. & $\begin{array}{l}6 \text { categories, ranging from ' } 1-3 \text { days per } \\
\text { month' to 'every day' }\end{array}$ & $\begin{array}{l}\text { Yes } \\
\text { Assessed separately } \\
\text { Subjects asked to select from a } \\
\text { range of portion for each food, } \\
\text { e.g. from ' } 100 \mathrm{ml} \text { o or less' to } \\
\text { '1000 ml or more.' Examples of } \\
\text { corresponding portions in grams } \\
\text { or millilitres provided for each } \\
\text { food item } \\
\text { Photo book included in appendix }\end{array}$ \\
\hline
\end{tabular}

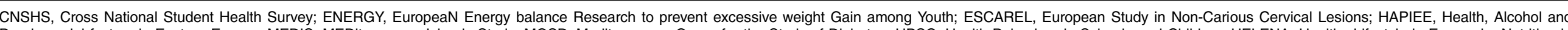

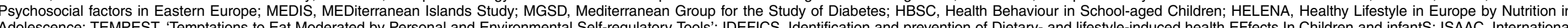
Adolescence, TEMPEST, Temptations to Eat Moderated by Personal and Environmental Selfregulatory Tools', IDEFICS, Identication and prevention of Dietary-and

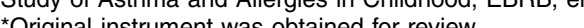

Information on the Food4Me instrument was obtained through contact with study authors. 


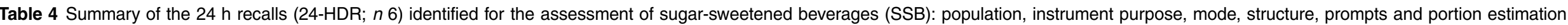

\begin{tabular}{|c|c|c|c|c|c|c|}
\hline Study & Population & Purpose & Mode & Structure & Prompts & Portion estimation \\
\hline $\operatorname{EPIC}^{(49,118)}$ & $\begin{array}{l}\text { Adults } \\
30-70 \text { years }\end{array}$ & $\begin{array}{l}\text { Provide comparable food } \\
\text { consumption data between } \\
\text { several European countries }\end{array}$ & $\begin{array}{l}\text { EPIC-SOFT } \\
\text { One 24-HDR } \\
\text { Computerised } \\
\text { Face-to-face interview }\end{array}$ & $\begin{array}{l}\text { 1. 'Quick list': chronological entry } \\
\text { of all foods and recipes } \\
\text { consumed during day } \\
\text { 2. Foods are entered per meal } \\
\text { 3. Each 'quick list' item is } \\
\text { described and quantified }\end{array}$ & $\begin{array}{l}\text { Yes. Program mediated } \\
\text { Checklist of easily forgotten foods }\end{array}$ & $\begin{array}{l}\text { Estimated } \\
\text { Six quantification methods including photos, shapes, household } \\
\text { measurements, standard units, standard portions, volume method } \\
\text { and 'unknown' method } \\
\text { 4-6 portion sizes }\end{array}$ \\
\hline HELENA ${ }^{(52,53,68)}$ & $\begin{array}{l}\text { Adolescents } \\
13-17 \text { years }\end{array}$ & Assess food and nutrient intakes & $\begin{array}{l}\text { HELENA-DIAT } \\
\text { Two non-consecutive } \\
24-H D R \text { (within } 2 \text { weeks) } \\
\text { Computerised }\end{array}$ & Six meal occasions & $\begin{array}{l}\text { Yes. Program mediated } \\
\text { Checked entries for the occurrence of } F \& V \\
\text { and sweets to ask adolescents if this was } \\
\text { 'really not consumed?' }\end{array}$ & $\begin{array}{l}\text { Estimated } \\
\text { Photographs } \\
\text { Standard units, e.g. spoon, can, glass, grams }\end{array}$ \\
\hline $\mathrm{EYHS}^{(46,48,78) *}$ & $\begin{array}{l}\text { Children } \\
9 \text { and } 15 \text { years }\end{array}$ & $\begin{array}{l}\text { Examine personal, environmental } \\
\text { and lifestyle influences on } \\
\text { cardiovascular risk factors } \\
\text { Examine changes in diet intake over } \\
\text { time } e^{(119)}\end{array}$ & $\begin{array}{l}\text { One } 24 \text {-HDR } \\
\text { Paper-based } \\
\text { Face-to-face recall interview } \\
\quad \text { preceded by } 1 \mathrm{~d} \\
\quad \text { qualitative food record }\end{array}$ & $\begin{array}{l}\text { Pre-coded food checklist on the } \\
24-H D R \\
\text { Recorded: type/description/ } \\
\text { location }\end{array}$ & Yes. During face-to-face interview & $\begin{array}{l}\text { Estimated } \\
\text { Different-sized drinking glasses, plates, spoons and food pictures of } \\
\text { most common foods and food groups in different portion sizes were } \\
\text { used to estimate food quantities }\end{array}$ \\
\hline ENERGY $^{(51,108) *}$ & $\begin{array}{l}\text { Children } \\
10-12 \text { years }\end{array}$ & $\begin{array}{l}\text { Determine prevalence of EBRB } \\
\text { Identify personal, family and school } \\
\text { environmental correlates of } \\
\text { EBRB }\end{array}$ & $\begin{array}{l}\text { One 24-HDR } \\
\text { Paper-based } \\
\text { Self-admin. }\end{array}$ & $\begin{array}{l}\text { Single question asked number of } \\
\text { 'Fizzy drinks or fruit squash' } \\
\text { consumed yesterday } \\
\text { Six options ranging from 'none' to } \\
\text { '5 or more' }\end{array}$ & No & $\begin{array}{l}\text { Estimated (in-line) } \\
\text { Subject can select number of glasses/small bottles }(250 \mathrm{ml}) \text {, cans } \\
\quad(330 \mathrm{ml}) \text { and bottles }(500 \mathrm{ml})\end{array}$ \\
\hline $\begin{array}{l}\text { IDEFICS }(39,40) \\
\text { (SACINA) }\end{array}$ & $\begin{array}{l}\text { Children } \\
\text { 2-9 years } \\
\text { (parents or } \\
\text { guardians as } \\
\text { proxies) }\end{array}$ & $\begin{array}{l}\text { Determine the aetiology of } \\
\text { overweight, obesity and related } \\
\text { disorders }\end{array}$ & $\begin{array}{l}\text { SACINA } \\
\text { One 24-HDR } \\
\text { Computerised } \\
\text { Face-to face-interview } \\
\text { Hungary: self-admin. 24- } \\
\quad \text { HDR completed at home }\end{array}$ & 6 meal occasions & $\begin{array}{l}\text { Yes. Program mediated } \\
\text { Showed intake and asked participants 'What } \\
\quad \text { food items are missing?' }\end{array}$ & $\begin{array}{l}\text { Estimated } \\
\text { Photographs, } 6 \text { glass sizes }\end{array}$ \\
\hline $\begin{array}{l}\text { I.Family } \\
\text { Project }^{(70) *}\end{array}$ & $\begin{array}{l}\text { Children and } \\
\text { adolescents } \\
8 \text { years or older } \\
\text { Parents } \\
\text { No age range } \\
\text { determined }\end{array}$ & $\begin{array}{l}\text { Identify determinants of food choice } \\
\text { and lifestyle }\end{array}$ & $\begin{array}{l}\text { SACANA } \\
\text { One 24-HDR } \\
\text { Online self-admin. }\end{array}$ & $\begin{array}{l}\text { Meal occasions } \\
1 \text { breakfast, } 1 \text { lunch, } 1 \text { dinner; } \\
\text { snacks and drinks as needed }\end{array}$ & Yes. Program mediated & $\begin{array}{l}\text { Accurate portion size in grams or millilitres and graphical images and } \\
\text { photos }\end{array}$ \\
\hline
\end{tabular}

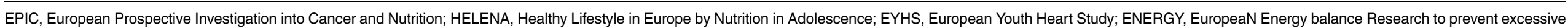

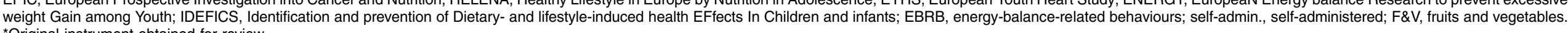
${ }^{*}$ Original instrument obtained for review. 
intake $^{(37)}$, ideally, an instrument should be tested for validity in the population in which it will be used and the purpose for which the instrument is intended should be taken into account. For example, most FFQ identified by the review were used to examine determinants of dietary intake or examine the diet-disease associations, in contrast to the 24-HDR and diet records which were used mainly to assess intake for cross-cultural comparisons, or over time. FFQ are typically designed to be population-specific, to capture dietary customs and foods ${ }^{(125)}$, and so the FFQ may not be the ideal instrument to use across several countries.

However, the current review has indicated how questions relating to SSB may best be structured, even across country-specific FFQ. For example, self-administered instruments should define SSB and provide examples to aid respondent comprehension. Furthermore, more than one item may be necessary to assess SSB; that is, the use of a single term such as 'soft drinks' to capture SSB may not be sufficient to fully assess intake of SSB as that term does not differentiate soft drinks, diet soft drinks and squashes. An agreement on a standardised way to assess SSB intake across instruments, including a requirement on assessing portion size in a systematic manner (i.e. clarifying units for participants, e.g. beaker $=250 \mathrm{ml}$ ), would be a key step in harmonising the data collection in different regions. The feasibility of using the instrument is also an important consideration. Of the seven instruments that were tested for validity, three were self-administered, paper-based FFQ (IDEFICS, ToyBox, HBSC) which may require less resources (i.e. Internet/computer, personnel and time resources) than online or computer-based self-administered FFQ (HELENA, Food4Me) or 24-HDR (HELENADIAT). As discussed in the paper on methods to assess F\&V intake ${ }^{(37)}$, suitability of the instrument, based on the purpose of the study, must be weighed against feasibility.

When reflecting on the best approach to assess SSB intake, balancing purpose against feasibility is particularly relevant. A 24-HDR or diet record can offer a more detailed and potentially more accurate ${ }^{(126)}$ account of an individual's SSB intake (particularly if records are maintained throughout the day by respondents, and/or prompted appropriately e.g. as part of HELENA-DIAT). Furthermore, as recalls or records capture SSB intake in the context of overall consumption for the day, they also offer the potential to explore intake in the light of other dietary components and dietary/meal patterns throughout the day; such as the association of consumption of sugarrich foods with skipped/missed meals or as a marker of poor diet quality ${ }^{(127)}$. However, given food intake has the potential to vary from day to day, it is generally accepted that where assessing an individual's usual intake is of interest, a single 24-HDR is not appropriate. As SSB ideally should be consumed on an occasional basis, it is possible that an assessment over a limited time period may not reliably reflect usual intake. Much of the current research around SSB has a strong policy focus, tracking global or country-level consumption frequency and relating this to wider health concerns such as obesity or type 2 diabetes $^{(11,16,128)}$. FFQ, particularly if made more comparable across regions (e.g. through standardising frequency categories and definitions of SSB), are valid for this purpose, and do not incur the same respondent burden and expense as the multiple 24-HDR or records which would be required to approximate an individual's usual intake. However, given the different opportunities offered by the different methodologies, it can be argued that to obtain a broader understanding of patterns of SSB consumption overall, both FFQ and diet records should be utilised. For example, the questionnaire used by the ENERGY study included elements of the FFQ and 24-HDR for the purposes of assessing SSB intake among children ${ }^{(51)}$.

The current review is strengthened by the use of a comprehensive, broad search strategy, supplemented by hand-searching reference lists. Instruments were sourced through contact with study authors and reviewing the results of the review on methods to assess $F \& V$ intake. However, there remains the possibility that we did not identify all relevant articles. It is important to note that where a copy of the original instrument or article could not be accessed, the instrument description may be limited. The review is limited to articles published up to June 2014 and we cannot exclude the possibility that new instruments to assess SSB may have become available since the review was completed. Although we would expect more recent instruments to be similar to those identified by our review (i.e. predominantly FFQ and 24-HDR), it is possible that further online tools may have been developed. The advent of tools such as the Food4Me and HELENA FFQ ${ }^{(55,106)}$, both which are administered online, suggests the move towards this approach, which also offers the opportunity for delivering personalised feedback messages on the basis of food intake data entered by participants.

While the review limited its focus to pan-European studies, as mentioned in the concurrent review on F\&V intake $^{(37)}$, this is not to assert that other instruments tested for validity as part of non-European studies would be unsuitable for assessing intakes across Europe. Beyond examining the outcomes of validation studies, as was the case when reviewing instruments to assess $F \& V$ intake ${ }^{(37)}$, the quality of the identified instruments was not assessed in the current review owing to the lack of an appraisal tool to rate dietary assessment instruments on the basis of their characteristics. As with the F\&V review ${ }^{(37)}$, comparing the characteristics of the instruments identified in the current review could inform how quality standards around dietary assessment instruments might be developed. Although the quality of each instrument could not be fully assessed, the review has provided a shortlist of potential instruments for use in future pan-European studies through selecting instruments that had been used across more than two European countries and those tested for validity for SSB intake. These results will contribute to the development of 
the DEDIPAC toolbox of dietary intake assessment methods, which should provide a basis for appraising and selecting suitable instruments to use in future pan-European studies.

\section{Conclusion}

The present review has identified a range of instruments to assess intake of SSB. Results indicate key differences between the identified instruments. In order to standardise and harmonise assessment methods between European countries and increase the accuracy with which intake of SSB is measured, it is essential that a clear and agreed definition of SSB be used: one which clearly explains what is captured by the term 'soft drinks', and which distinguishes between sugar-free or light drinks and sugared drinks, and between pure fruit juices and squashes. The review has indicated seven methods that were tested for validity and used in pan-European studies. These methods may be most suitable to assess the intake of SSB among adult, child or adolescent populations in future panEuropean studies.

\section{Acknowledgements}

Financial support: The preparation of this paper was supported by the DEDIPAC Knowledge Hub. This work was supported by the Joint Programming Initiative 'Healthy Diet for a Healthy Life'. The funding agency supporting this work was The Health Research Board (HRB), Ireland (DEDIPAC/2013/1). Conflicts of interest: None. Authorship: F.R. planned and conducted the review, and drafted and revised the paper. K.R. planned and conducted the review, and drafted the paper. I.J.P. drafted and revised the paper. M.B.S. contributed to the planning, and drafted and revised the paper. L.F.A. contributed to the planning, and drafted and revised the paper. A.G. drafted and revised the paper. P.v.V. drafted and revised the paper. S.E. conducted the review of validation data, and drafted and revised the paper. M.v.D. conducted the review of validation data, and drafted and revised the paper. N.W.-D. conducted the review of validation data, and drafted and revised the paper. J.M.H. contributed to the planning, and drafted and revised the paper. Ethics of buman subject participation: Not applicable.

\section{Supplementary material}

To view supplementary material for this article, please visit http://dx.doi.org/10.1017/S1368980016002639

\section{References}

1. Hanson C, Rutten EP, Wouters EF et al. (2013) Diet and vitamin $\mathrm{D}$ as risk factors for lung impairment and COPD. Transl Res 162, 219-236.
2. World Health Organization (2003) Diet, Nutrition and the Prevention of Chronic Diseases. Report of a Joint WHO/ FAO Expert Consultation. WHO Technical Report Series no. 916. Geneva: WHO

3. Aburto NJ, Ziolkovska A, Hooper L et al. (2013) Effect of lower sodium intake on health: systematic review and meta-analyses. BMJ 346, f1326.

4. Walda IC, Tabak C, Smit HA et al. (2002) Diet and 20-year chronic obstructive pulmonary disease mortality in middle-aged men from three European countries. Eur J Clin Nutr 56, 638-643.

5. Dhingra R, Sullivan L, Jacques PF et al. (2007) Soft drink consumption and risk of developing cardiometabolic risk factors and the metabolic syndrome in middle-aged adults in the community. Circulation 116, 480-488.

6. Malik VS, Popkin BM, Bray GA et al. (2010) Sugarsweetened beverages and risk of metabolic syndrome and type 2 diabetes: a meta-analysis. Diabetes Care $\mathbf{3 3}$, $2477-2483$.

7. Vartanian LR, Schwartz MB \& Brownell KD (2007) Effects of soft drink consumption on nutrition and health: a systematic review and meta-analysis. Am J Public Health 97, 667-675.

8. Malik VS, Pan A, Willett WC et al. (2013) Sugar-sweetened beverages and weight gain in children and adults: a systematic review and meta-analysis. Am J Clin Nutr 98, 1084-1102.

9. Waxman A (2004) WHO global strategy on diet, physical activity and health. Food Nutr Bull 25, 292-302.

10. Popkin BM \& Nielsen SJ (2003) The sweetening of the world's diet. Obes Res 11, 1325-1332.

11. Popkin BM \& Hawkes C (2016) Sweetening of the global diet, particularly beverages: patterns, trends, and policy responses. Lancet Diabetes Endocrinol 4, 174-186.

12. Irish Heart Foundation (2013) Pre-Budget Submission 2014. Dublin: Irish Heart Foundation.

13. Finucane MM, Stevens GA, Cowan MJ et al. (2011) National, regional, and global trends in body-mass index since 1980: systematic analysis of health examination surveys and epidemiological studies with 960 country-years and 9.1 million participants. Lancet 377, $557-567$.

14. Organisation for Economic Co-operation and Development (2012) Health at a Glance: Europe 2012. Paris: OECD Publishing.

15. Hu FB (2013) Resolved: there is sufficient scientific evidence that decreasing sugar-sweetened beverage consumption will reduce the prevalence of obesity and obesity-related diseases. Obes Rev 14, 606-619.

16. Imamura F, O'Connor L, Ye Z et al. (2015) Consumption of sugar sweetened beverages, artificially sweetened beverages, and fruit juice and incidence of type 2 diabetes: systematic review, meta-analysis, and estimation of population attributable fraction. BMJ 351, h3576.

17. Gibson S (2008) Sugar-sweetened soft drinks and obesity: a systematic review of the evidence from observational studies and interventions. Nutr Res Rev 21, 134-147.

18. Malik VS, Schulze MB \& Hu FB (2006) Intake of sugarsweetened beverages and weight gain: a systematic review. Am J Clin Nutr 84, 274-288.

19. Trumbo PR \& Rivers CR (2014) Systematic review of the evidence for an association between sugar-sweetened beverage consumption and risk of obesity. Nutr Rev 72, 566-574.

20. Ebbeling CB, Feldman HA, Chomitz VR et al. (2012) A randomized trial of sugar-sweetened beverages and adolescent body weight. $N$ Engl J Med 367, 1407-1416.

21. de Ruyter JC, Olthof MR, Seidell JC et al. (2012) A trial of sugar-free or sugar-sweetened beverages and body weight in children. $N$ Engl J Med 367, 1397-1406. 
22. Caprio S (2012) Calories from soft drinks - do they matter? $N$ Engl J Med 367, 1462-1463.

23. Blanquer M, Garcia-Alvarez A, Ribas-Barba L et al. (2009) How to find information on national food and nutrient consumption surveys across Europe: systematic literature review and questionnaires to selected country experts are both good strategies. Br J Nutr 101, Suppl. 2, S37-S50.

24. National and Kapodistrian University of Athens (2014) DAFNE. Data Food Networking. http://www.nut.uoa.gr/ dafnesoftweb/. (accessed September 2014).

25. Castenmiller J \& West CE (1995) Report of the Third Annual FLAIR-Eurofoods-Enfant Project Meeting, Vilamoura, Portugal, 1993. Wageningen: FLAIR-EurofoodsEnfant Project (1994).

26. Working Group on Food Data Management and Interchange (2000) COST Action 99. Research Action on Food Consumption and Composition Data, Eurofoods Recommendations for Food Composition Database Management and Data Interchange. Luxembourg: Office for Official Publications of the European Communities.

27. Norfoods project (2014) A Nordic approach to Food Composition Data. http://www.fooddata.dk/norfoods/? Nordic_food_data (accessed September 2014).

28. EFCOSUM Group (2001) European Food Consumption Survey Method, Final Report. TNO Report no. V3766. Zeist: TNO Nutrition and Food Research.

29. Riboli E \& Kaaks R (1997) The EPIC Project: rationale and study design. European Prospective Investigation into Cancer and Nutrition. Int J Epidemiol 26, Suppl. 1, S6-S14.

30. Innovative Dietary Assessment Methods in Epidemiological Studies and Public Health (2010) Dietary Assessment Methods: State of the Art Report. Potsdam-Rehbrücke: German Institute of Human Nutrition (DIfE).

31. European Food Safety Authority (2009) General principles for the collection of national food consumption data in the view of a pan-European dietary survey. EFSA J 7, 1435.

32. European Food Safety Authority (2014) Guidance on the EU Menu methodology. EFSA J 12, 3944.

33. Determinants of Diet and Physical Activity Knowledge Hub (2014) Home page. https://www.dedipac.eu/ (accessed September 2014).

34. Lakerveld J, van der Ploeg H, Kroeze W et al. (2014) Towards the integration and development of a crossEuropean research network and infrastructure: the DEterminants of DIet and Physical ACtivity (DEDIPAC) Knowledge Hub. Int J Behav Nutr Phys Act 11, 143.

35. Harrington JM, Riordan F \& Ryan K (2014) What are the assessment methods used to determine dietary intake of sugar-sweetened beverages in adults ( $>18$ years) and children in European countries, according to panEuropean studies involving two or more European countries? (Protocol). http://www.crd.york.ac.uk/PROSPERO/ display_record.asp?ID=CRD42014012890 (accessed September 2016).

36. Council of Europe (2014) 47 Member States. http://www. coe.int/en/web/portal/47-members-states (accessed September 2014).

37. Riordan F, Ryan K, Perry IJ et al. (2016) A systematic review of methods to assess intake of fruits and vegetables among healthy European adults and children: a DEDIPAC (DEterminants of DIet and Physical Activity) study. Public Health Nutr (Epublication ahead of print version).

38. United Nations (2014) Composition of macro geographical (continental) regions, geographical sub-regions, and selected economic and other groupings. http://unstats.un. org/unsd/methods/m49/m49regin.htm (accessed March 2014).

39. Ahrens W, Bammann K, Siani A et al. (2011) The IDEFICS cohort: design, characteristics and participation in the baseline survey. Int J Obes (Lond) 35, Suppl. 1, S3-S15.
40. Bel-Serrat S, Mouratidou T, Pala V et al. (2014) Relative validity of the Children's Eating Habits Questionnairefood frequency section among young European children: the IDEFICS Study. Public Health Nutr 17, 266-276.

41. Currie C, Griebler R, Inchley J et al. (2010) Health Behaviour in School-Aged Children (HBSC) Study Protocol: Background, Methodology and Mandatory Items for the 2009/10 Survey. Edinburgh/Vienna: CAHRU/LBIHPR.

42. de Groot CPGM \& van Staveren WA (1988) Nutrition and the Elderly. A European Collaborative Study in Cooperation with the World Health Organization (WHO-SPRA) and the International Union of Nutritional Sciences (IUNS) Committee on Geriatric Nutrition, Manual of Operations. EURO-NUT Report no. 11. Wageningen: EURONUT.

43. de Groot LC, Hautvast JG \& van Staveren WA (1992) Nutrition and health of elderly people in Europe: the EURONUT-SENECA Study. Nutr Rev 50, 185-194.

44. Moreno LA, De Henauw S, Gonzalez-Gross M et al. (2008) Design and implementation of the Healthy Lifestyle in Europe by Nutrition in Adolescence Cross-Sectional Study. Int J Obes (Lond) 32, Suppl. 5, S4-S11.

45. Moreno LA, Gonzalez-Gross M, Kersting M et al. (2008) Assessing, understanding and modifying nutritional status, eating habits and physical activity in European adolescents: the HELENA (Healthy Lifestyle in Europe by Nutrition in Adolescence) Study. Public Health Nutr 11, 288-299.

46. Olsen NJ, Andersen LB, Wedderkopp N et al. (2012) Intake of liquid and solid sucrose in relation to changes in body fatness over 6 years among 8- to 10-year-old children: the European Youth Heart Study. Obes Facts $\mathbf{5}$, 506-512.

47. Riboli E, Hunt KJ, Slimani N et al. (2002) European Prospective Investigation into Cancer and Nutrition (EPIC): study populations and data collection. Public Health Nutr 5. 1113-1124.

48. Riddoch C, Edwards D, Page A et al. (2005) The European Youth Heart Study - cardiovascular disease risk factors in children: rationale, aims, study design, and validation of methods. J Phys Act Health 2, 115-129.

49. Slimani N, Deharveng G, Charrondiere RU et al. (1999) Structure of the standardized computerized 24-h diet recall interview used as reference method in the 22 centers participating in the EPIC project. European Prospective Investigation into Cancer and Nutrition. Comput Methods Programs Biomed 58, 251-266.

50. van Staveren WA, de Groot LC, Burema J et al. (1995) Energy balance and health in SENECA participants. Survey in Europe on Nutrition and the Elderly, a Concerted Action. Proc Nutr Soc 54, 617-629.

51. van Stralen MM, te Velde SJ, Singh AS et al. (2011) EuropeaN Energy balance Research to prevent excessive weight Gain among Youth (ENERGY) project: design and methodology of the ENERGY cross-sectional survey. BMC Public Health 11, 65.

52. Vereecken CA, Covents M, Matthys C et al. (2005) Young adolescents' nutrition assessment on computer (YANA-C). Eur J Clin Nutr 59, 658-667.

53. Vereecken CA, Covents M, Sichert-Hellert W et al. (2008) Development and evaluation of a self-administered computerized 24-h dietary recall method for adolescents in Europe. Int J Obes (Lond) 32, Suppl. 5, S26-S34.

54. Vereecken CA, De Bourdeaudhuij I \& Maes L (2010) The HELENA online food frequency questionnaire: reproducibility and comparison with four 24-h recalls in BelgianFlemish adolescents. Eur J Clin Nutr 64, 541-548.

55. Maes L, Cook TL, Ottovaere C et al. (2011) Pilot evaluation of the HELENA (Healthy Lifestyle in Europe by Nutrition in Adolescence) Food-O-Meter, a computer-tailored nutrition 
advice for adolescents: a study in six European cities. Public Health Nutr 14, 1292-1302.

56. El Ansari W, Stock C \& Mikolajczyk RT (2012) Relationships between food consumption and living arrangements among university students in four European countries - a cross-sectional study. Nutr J 11, 28.

57. Mikolajczyk RT, El Ansari W \& Maxwell AE (2009) Food consumption frequency and perceived stress and depressive symptoms among students in three European countries. Nutr J 8, 31 .

58. Boylan S, Welch A, Pikhart H et al. (2009) Dietary habits in three Central and Eastern European countries: the HAPIEE study. BMC Public Health 9, 439.

59. Peasey A, Bobak M, Kubinova R et al. (2006) Determinants of cardiovascular disease and other non-communicable diseases in Central and Eastern Europe: rationale and design of the HAPIEE study. BMC Public Health 6, 255.

60. Prattala R, Paalanen L, Grinberga D et al. (2007) Gender differences in the consumption of meat, fruit and vegetables are similar in Finland and the Baltic countries. Eur J Public Health 17, 520-525.

61. Tyrovolas S, Psaltopoulou T, Pounis G et al. (2011) Nutrient intake in relation to central and overall obesity status among elderly people living in the Mediterranean islands: the MEDIS study. Nutr Metab Cardiovasc Dis 21, 438-445.

62. Karamanos B, Thanopoulou A, Angelico F et al. (2002) Nutritional habits in the Mediterranean Basin. The macronutrient composition of diet and its relation with the tradiational Mediterranean diet. Multi-centre study of the Mediterranean Group for the study of diabetes (MGSD). Eur J Clin Nutr 56, 983-991.

63. Weiland SK, Bjorksten B, Brunekreef B et al. (2004) Phase II of the International Study of Asthma and Allergies in Childhood (ISAAC II): rationale and methods. Eur Respir J 24, 406-412.

64. Nagel G, Weinmayr G, Kleiner A et al. (2010) Effect of diet on asthma and allergic sensitisation in the international study on allergies and asthma in childhood (ISAAC) phase two. Thorax $\mathbf{6 5}, 516-522$.

65. Paalanen L, Prattala R, Palosuo H et al. (2011) Socioeconomic differences in the consumption of vegetables, fruit and berries in Russian and Finnish Karelia: 1992-2007. Eur J Public Health 21, 35-42.

66. I.Family (2014) Home page. http://www.ifamilystudy.eu/ (accessed September 2014).

67. Zaborskis A, Moceviciene R \& Iannotti RJ (2014) The influence of chronological period of data collection on differences in reported dietary intake among school-aged children surveyed in 39 countries. J Nutr Educ Behav $\mathbf{4 6}$, 359-369.

68. Duffey KJ, Huybrechts I, Mouratidou T et al. (2012) Beverage consumption among European adolescents in the HELENA study. Eur J Clin Nutr 66, 244-252.

69. Determinants of eating behaviour in European children, adolescents and their parents (I.Family) (2012-2017) Diet Questionnaire. EC FP7 Grant Agreement no. 266044.

70. Determinants of eating behaviour in European children, adolescents and their parents (I.Family) (2012-2017) SACANA. EC FP7 Grant Agreement no. 266044.

71. Larsson CL, Klock KS, Astrom AN et al. (2001) Food habits of young Swedish and Norwegian vegetarians and omnivores. Public Health Nutr 4, 1005-1014.

72. Szczepanska E, Deka M \& Calyniuk B (2013) Studies to determine nutrition behaviour amongst middle school pupils living in the border areas of Poland and the Czech Republic. Rocz Panstw Zakl Hig 64, 191-196.

73. Luszczynska A, de Wit JB, de Vet E et al. (2013) At-home environment, out-of-home environment, snacks and sweetened beverages intake in preadolescence, early and mid-adolescence: the interplay between environment and self-regulation. $J$ Youth Adolesc 42, 1873-1883.

74. de Vet E, de Wit JB, Luszczynska A et al. (2013) Access to excess: how do adolescents deal with unhealthy foods in their environment? Eur J Public Health 23, 752-756.

75. Stok FM, de Vet E, de Wit JB et al. (2015) The proof is in the eating: subjective peer norms are associated with adolescents' eating behaviour. Public Health Nutr 18, 1044-1051.

76. Cinar B \& Murtomaa H (2008) Clustering of obesity and dental health with lifestyle factors among Turkish and Finnish pre-adolescents. Obes Facts 1, 196-202.

77. Brug J, van Stralen MM, Te Velde SJ et al. (2012) Differences in weight status and energy-balance related behaviors among schoolchildren across Europe: the ENERGYproject. PLoS One 7, e34742.

78. Zheng M, Rangan A, Olsen NJ et al. (2014) Sugarsweetened beverages consumption in relation to changes in body fatness over 6 and 12 years among 9-year-old children: the European Youth Heart Study. Eur J Clin Nutr 68, 77-83.

79. Olafsdottir S, Berg C, Eiben G et al. (2014) Young children's screen activities, sweet drink consumption and anthropometry: results from a prospective European study. Eur J Clin Nutr 68, 223-228.

80. Manios Y, Androutsos O, Katsarou C et al. (2014) Designing and implementing a kindergarten-based, family-involved intervention to prevent obesity in early childhood: the ToyBox-study. Obes Rev 15, Suppl. 3, 5-13.

81. Manios Y \& ToyBox-study G (2014) Methodological procedures followed in a kindergarten-based, family-involved intervention implemented in six European countries to prevent obesity in early childhood: the ToyBox-study. Obes Rev 15, Suppl. 3, 1-4.

82. Mouratidou T, Miguel ML, Androutsos O et al. (2014) Tools, harmonization and standardization procedures of the impact and outcome evaluation indices obtained during a kindergarten-based, family-involved intervention to prevent obesity in early childhood: the ToyBox-study. Obes Rev 15, Suppl. 3, 53-60.

83. Gonzalez-Gil EM, Mouratidou T, Cardon G et al. (2014) Reliability of primary caregivers reports on lifestyle behaviours of European pre-school children: the ToyBoxstudy. Obes Rev 15, Suppl. 3, 61-66.

84. De Craemer M, De Decker E, De Bourdeaudhuij I et al. (2014) Applying the intervention mapping protocol to develop a kindergarten-based, family-involved intervention to increase European preschool children's physical activity levels: the ToyBox-study. Obes Rev 15, Suppl. 3, $14-26$.

85. Duvinage K, Ibrügger S, Kreichauf S et al. (2014) Developing the intervention material to increase physical activity levels of European preschool children: the ToyBox-study. Obes Rev 15, Suppl. 3, 27-39.

86. Payr A, Birnbaum J, Wildgruber A et al. (2014) Concepts and strategies on how to train and motivate teachers to implement a kindergarten-based, family-involved intervention to prevent obesity in early childhood. The ToyBox-study. Obes Rev 15, Suppl. 3, 40-47.

87. Androutsos O, Katsarou C, Payr A et al. (2014) Designing and implementing teachers' training sessions in a kindergarten-based, family-involved intervention to prevent obesity in early childhood. The ToyBox-study. Obes Rev 15, Suppl. 3, 48-52.

88. De Miguel-Etayo P, Mesana MI, Cardon G et al. (2014) Reliability of anthropometric measurements in European preschool children: the ToyBox-study. Obes Rev 15, Suppl. 3, 67-73.

89. Androutsos O, Apostolidou E, Iotova V et al. (2014) Process evaluation design and tools used in a kindergarten-based, 
family-involved intervention to prevent obesity in early childhood. The ToyBox-study. Obes Rev 15, Suppl. 3, 74-80.

90. Pil L, Putman K, Cardon G et al. (2014) Establishing a method to estimate the cost-effectiveness of a kindergarten-based, family-involved intervention to prevent obesity in early childhood. The ToyBox-study. Obes Rev 15, Suppl. 3, 81-89.

91. Crispim SP, Geelen A, Souverein OW et al. (2011) Biomarker-based evaluation of two 24-h recalls for comparing usual fish, fruit and vegetable intakes across European centers in the EFCOVAL Study. Eur J Clin Nutr 65, Suppl. 1, S38-S47.

92. Margetts BM \& Pietinen P (1997) European Prospective Investigation into Cancer and Nutrition: validity studies on dietary assessment methods. Int J Epidemiol 26, Suppl. 1, S1-S5.

93. Brunner E, Stallone D, Juneja M et al. (2001) Dietary assessment in Whitehall II: comparison of $7 \mathrm{~d}$ diet diary and food-frequency questionnaire and validity against biomarkers. Br J Nutr 86, 405-414.

94. Willett WC, Sampson L, Stampfer MJ et al. (1985) Reproducibility and validity of a semiquantitative food frequency questionnaire. Am J Epidemiol 122, 51-65.

95. Tyrovolas S, Pounis G, Bountziouka V et al. (2010) Repeatability and validation of a short, semi-quantitative food frequency questionnaire designed for older adults living in Mediterranean areas: the MEDIS-FFQ. J Nutr Elder 29, 311-324.

96. Nes M, van Staveren WA, Zajkas G et al. (1991) Validity of the dietary history method in elderly subjects. Euronut SENECA investigators. Eur J Clin Nutr 45, Suppl. 3, 97-104.

97. Vereecken CA \& Maes L (2003) A Belgian study on the reliability and relative validity of the Health Behaviour in School-Aged Children food-frequency questionnaire. Public Health Nutr 6, 581-588.

98. Singh AS, Vik FN, Chinapaw MJM et al. (2011) Test-retest reliability and construct validity of the ENERGY-child questionnaire on energy balance-related behaviours and their potential determinants: the ENERGY-project. Int $J$ Behav Nutr Phys Act 8, 136.

99. Lytle LA, Nichaman MZ, Obarzanek E et al. (1993) Validation of 24-hour recalls assisted by food records in thirdgrade children. The CATCH Collaborative Group. J Am Diet Assoc 93, 1431-1436.

100. Huybrechts I, De Backer G, De Bacquer D et al. (2009) Relative validity and reproducibility of a food-frequency questionnaire for estimating food intakes among Flemish preschoolers. Int J Environ Res Public Health 6, 382-399.

101. Huybrechts I, Bornhorst C, Pala V et al. (2011) Evaluation of the Children's Eating Habits Questionnaire used in the IDEFICS study by relating urinary calcium and potassium to milk consumption frequencies among European children. Int J Obes (Lond) 35, Suppl. 1, S69-S78.

102. Haveman-Nies A, De Groot LCPGM \& Van Staveren WA (1998) Snack patterns of older Europeans. J Am Diet Assoc 98, 1297-1302.

103. Celis-Morales C, Livingstone KM, Marsaux CF et al. (2015) Design and baseline characteristics of the Food4Me study: a web-based randomised controlled trial of personalised nutrition in seven European countries. Genes Nutr 10, 450.

104. Fallaize R, Forster H, Macready AL et al. (2014) Online dietary intake estimation: reproducibility and validity of the Food4Me food frequency questionnaire against a 4-day weighed food record. J Med Internet Res 16, e190.

105. Forster H, Fallaize R, Gallagher C et al. (2014) Online dietary intake estimation: the Food $4 \mathrm{Me}$ food frequency questionnaire. J Med Internet Res 16, e150.
106. Tyrovolas S, Psaltopoulou T, Pounis G et al. (2011) Nutrient intake in relation to central and overall obesity status among elderly people living in the Mediterranean islands: The MEDIS study. Nutr Metab Cardiovas Dis 21, 438-445.

107. Kolarzyk E, Shpakou A, Kleszczewska E et al. (2012) Nutritional status and food choices among frst year medical students. Cent Eur J Med 7, 396-408.

108. Brug J, Van Stralen MM, Chinapaw MJ et al. (2012) Differences in weight status and energy-balance related behaviours according to ethnic background among adolescents in seven countries in Europe: the ENERGYproject. Pediatr Obes 7, 399-411.

109. Wirfalt E, McTaggart A, Pala V et al. (2002) Food sources of carbohydrates in a European cohort of adults. Public Health Nutr 5, 1197-1215.

110. West NX, Sanz M, Lussi A et al. (2013) Prevalence of dentine hypersensitivity and study of associated factors: a European population-based cross-sectional study. J Dent 41, 841-851.

111. Prattala R, Paalanen L, Grinberga D et al. (2007) Gender differences in the consumption of meat, fruit and vegetables are similar in Finland and the Baltic countries. Eur J Public Health 17, 520-525.

112. Lanfer A, Hebestreit A, Ahrens W et al. (2011) Reproducibility of food consumption frequencies derived from the Children's Eating Habits Questionnaire used in the IDEFICS study. Int J Obes (Lond) 35, Suppl. 1, S61-S68.

113. Bel-Serrat S, Fernandez Alvira JM, Pala V et al.2011) Relative validation of two dietary assessment methods: SACINA (24-h recall) and food frequency questionnaire. In 1st IDEFICS Symposium and Workshop Child Health in Europe - The IDEFICS Study: Towards a Better Understanding of Obesity; 2010, Nov 8-9; Zaragoza, Spain. Int J Obes (Lond) 35, Suppl. 1, S152 (abstract).

114. Bornhorst C, Bel-Serrat S, Pigeot I et al. (2014) Validity of 24-h recalls in (pre-)school aged children: comparison of proxy-reported energy intakes with measured energy expenditure. Clin Nutr 33, 79-84.

115. Boylan S, Lallukka T, Lahelma E et al. (2011) Socioeconomic circumstances and food habits in Eastern, Central and Western European populations. Public Health Nutr 14, 678-687.

116. Bel-Serrat S, Mouratidou T, Bornhorst C et al. (2013) Food consumption and cardiovascular risk factors in European children: the IDEFICS study. Pediatr Obes $\mathbf{8}$, 225-236.

117. Pala V, Lissner L, Hebestreit A et al. (2013) Dietary patterns and longitudinal change in body mass in European children: a follow-up study on the IDEFICS multicenter cohort. Eur J Clin Nutr 67, 1042-1049.

118. Slimani N, Kaaks R, Ferrari P et al. (2002) European Prospective Investigation into Cancer and Nutrition (EPIC) calibration study: rationale, design and population characteristics. Public Health Nutr 5, 1125-1145.

119. Patterson E, Warnberg J, Kearney J et al. (2009) The tracking of dietary intakes of children and adolescents in Sweden over six years: the European Youth Heart Study. Int J Behav Nutr Phys Act 6, 91.

120. Vandevijvere S, Geelen A, Gonzalez-Gross M et al. (2013) Evaluation of food and nutrient intake assessment using concentration biomarkers in European adolescents from the Healthy Lifestyle in Europe by Nutrition in Adolescence study. Br J Nutr 109, 736-747.

121. Bel-Serrat S, Mouratidou T, Santaliestra-Pasias AM et al. (2013) Clustering of multiple lifestyle behaviours and its association to cardiovascular risk factors in children: the IDEFICS study. Eur J Clin Nutr 67, 848-854.

122. Slimani N, Fahey M, Welch AA et al. (2002) Diversity of dietary patterns observed in the European Prospective 
Investigation into Cancer and Nutrition (EPIC) project. Public Health Nutr 5, 1311-1328.

123. Schroll K, Moreiras-Varela O, Schlettwein-Gsell D et al. (1997) Cross-cultural variations and changes in food-group intake among elderly women in Europe: results from the Survey in Europe on Nutrition and the Elderly a Concerted Action (SENECA). Am J Clin Nutr 65, 4 Suppl., S1282-S1289.

124. Cade J, Thompson R, Burley V et al. (2002) Development, validation and utilisation of food-frequency questionnaires a review. Public Health Nutr 5, 567-587.

125. Thompson FE \& Subar AF (2001) Dietary assessment methodology. In Nutrition in the Prevention and
Treatment of Disease, pp. 3-30 [M Ferruzzi, AM Coulston and Carol Boushy, editors]. San Diego, CA: Academic Press.

126. Burrows T, Martin R \& Collins C (2010) A systematic review of the validity of dietary assessment methods in children when compared with method of doubly labeled water. J Am Diet Assoc 110, 1501-1510.

127. Sjoberg A, Hallberg L, Hoglund D et al. (2003) Meal pattern, food choice, nutrient intake and lifestyle factors in the Goteborg Adolescence Study. Eur J Clin Nutr 57, 1569-1578.

128. Malik VS, Popkin BM, Bray GA et al. (2010) Sugar sweetened beverages, obesity, type 2 diabetes and cardiovascular disease risk. Circulation 121, 1356-1364. 